\title{
Mafic, large-volume, pyroclastic density current deposits from phreatomagmatic eruptions in the Ferrar large igneous province, Antarctica
}

\author{
Pierre-Simon Ross ${ }^{*}$ and James D.L. White \\ Department of Geology, University of Otago, PO Box 56, Dunedin, New Zealand \\ * Corresponding author
}

\begin{abstract}
Mafic volcaniclastic deposits are increasingly recognized as important components of continental flood basalt provinces, but the mode of origin of these deposits and the possible environmental influence of the eruptions that formed them remain poorly constrained. The Mawson Formation (Ferrar large igneous province, Jurassic) contains the best known examples of large-scale, mafic, primary pyroclastic deposits from any flood basalt province worldwide. At southern Allan Hills, in contrast with other sites, the Mawson Formation consists predominantly of sub-horizontal, laterally-continuous, meter-thick layers which fall into four facies: (1) poorly sorted, coarse lapilli-tuff or tuff-breccia beds; (2) tuff or fine lapilli-tuff beds; (3) block-rich layers; (4) accretionary lapilli-bearing beds. We interpret the first facies as deposits of high-concentration pyroclastic density currents (PDCs) resulting from the collapse of phreatomagmatic eruption plumes, some from a source probably several kilometers away in Coombs Hills. The finergrained layers were probably deposited by dilute PDCs, whereas block-rich layers originated from local sources predominantly by lateral ejection and ballistic fall. Dilute, moist turbulent currents were also likely responsible for the generation and deposition of large (up to $4.5 \mathrm{~cm}$ ) rim-type accretionary lapilli. Emplacement of meters-thick basaltic PDC deposits over areas of at least $100-200 \mathrm{~km}^{2}$ is suggested, with individual deposit volumes on the order of a cubic kilometer. Pre-lava pyroclastic eruptions of the Ferrar mafic magmas were explosive, produced significant eruption clouds, and distributed their products over substantial areas.
\end{abstract}

\begin{abstract}
Introduction
The Ferrar large igneous province (Jurassic) is one of several flood basalt provinces in which mafic volcaniclastic deposits exist; most of these fragmental deposits are probably the products of magma-water or magma-wet sediment interaction, at least in the betterstudied provinces (see Ross et al. 2005 for a review). Mafic volcaniclastic rocks associated with the Ferrar province, including the Mawson Formation, are up to $400 \mathrm{~m}$ in exposed thickness, and crop out for $>1000 \mathrm{~km}$ under the Kirkpatrick flood basalts along the Transantarctic Mountains (figs. 1a, b). The mafic volcaniclastic deposits in the Ferrar and Karoo provinces have been previously interpreted as either (1) filling large self-generated depressions, sometimes referred to as 'phreatocauldrons' (White and McClintock 2001; McClintock et al. 2003; Elliot et al. 2003, 2004) or (2) the products of eruption-fed lahars, perhaps filling preexisting topographic depressions (Hanson and Elliot 1996; Elliot and Hanson 2001; Skilling et al. 2001; Elliot 2002). Some of the just-cited publications propose one of the above interpretations for the Mawson Formation at southern Allan Hills but to our knowledge, none of those are based on actual outcrop observations. In this paper, we describe these well-exposed rocks in detail and conclude that the volumetrically dominant facies association, consisting of thick volcaniclastic layers, was
\end{abstract}

deposited principally by pyroclastic density currents (PDCs), into a pre-existing topographic depression rather than a newly excavated phreatocauldron. We infer that most of the PDCs were high-concentration flows and resulted from the collapse of sustained basaltic phreatomagmatic eruption plumes.

\section{Geological context}

Ferrar rocks are exposed in a belt $>3000 \mathrm{~km}$ long but less than $200 \mathrm{~km}$ wide in the Transantarctic Mountains (Elliot 1992; fig. 1a). The large igneous province consists of the Ferrar Dolerite (mafic sills and dikes), the Dufek Intrusion (a layered igneous complex), the Kirkpatrick Basalt (flood lavas), and mafic volcaniclastic deposits belonging to the Exposure Hill Formation (Elliot et al. 1986), the Mawson Formation (Gunn and Warren 1962) and the Prebble Formation (Hanson and Elliot 1996; fig. 1b). These volcaniclastic units overlie and in places invade sedimentary rocks of the Devonian to Jurassic(?) Beacon Supergroup (Barrett 1991).

Allan Hills is located on the edge of the polar plateau (fig. 1c). It lies only a few kilometers away from Coombs Hills where the Mawson Formation, though including minor layered deposits, consists predominantly of over 300 vertical meters of non-bedded, poorly sorted coarse lapilli-tuffs and tuff-breccias (Elliot 2000) that have been interpreted as filling a $\geq 5 \mathrm{~km}$-wide 
phreatomagmatic vent complex (White and McClintock 2001; McClintock and White 2005). The approximate limit of this complex is shown by the bold dashed line on figure 1d. The Mawson Formation at Coombs Hills always contains at least $30 \%$ basaltic clasts, but this is not the case at Allan Hills, where the formation can be divided into two members, $\mathrm{m}_{1}$ and $\mathrm{m}_{2}$ (Reubi et al. 2005; fig. 1d). Member $\mathrm{m}_{2}$ resembles the "normal" Mawson Formation of Coombs Hills in terms of componentry but $\mathrm{m}_{1}$, occurring only at central Allan Hills, is significantly depleted in basaltic clasts, strongly enriched in Beacon clasts and megablocks (up to $80 \mathrm{~m}$ in length), and is interpreted as the $\geq 180$ m-thick deposit of a single, north-east flowing debris avalanche (see Reubi et al. 2005 for more information on $\mathrm{m}_{1}$ ). In contrast, outcrop in southern Allan Hills is exclusively of $m_{2}$ (this paper), with neither the Beacon Supergroup sequence nor the $m_{1}$ member of the Mawson Formation exposed.

\section{Description of the lithofacies and facies associations}

The Mawson Formation at southern Allan Hills consists, in decreasing outcrop area, of (i) thick volcaniclastic layers; (ii) non-bedded, poorly sorted, basalt-rich tuffbreccias; (iii) thin volcaniclastic layers; (iv) volcaniclastic dikes (fig. 2, table 1), all of which belong to member $m_{2}$. The general relationships among these lithofacies and facies associations are as follows: the thick-layer association overlies (and is locally interbedded with) the thin layers; both thin and thick layers overlie and/or are invaded by the non-bedded basalt-rich tuff-breccias; and finally, the volcaniclastic dikes cross-cut everything else (see the cross-sections on fig. 2).

Facies association: thick volcaniclastic layers. The thick-layer association includes four facies: (1) poorly sorted, coarse lapilli-tuff or tuff-breccia beds; (2) fine lapilli-tuff or tuff beds; (3) block-rich layers; and (4) accretionary lapilli-bearing layers (table 1, figs. 3-5). Beds of the latter two facies, as well as a distinctive Beacon-rich coarse lapilli-tuff ("gray layer", part of facies 1), serve as marker horizons. Some block-rich layers and the gray layer can be followed laterally without interruption for several hundred meters, and are easily traced, with limited interpolation, for kilometers; this demonstrates beyond doubt the layered character of the Mawson in southern Allan Hills. No paleosols, epiclastic sediments, unconformities or evidence for erosion or reworking by water or wind were observed.

Facies 1: poorly sorted, coarse lapilli-tuff or tuff-breccia beds. Most of the thick-layer association consists of internally structureless, unwelded, poorly sorted coarse lapilli-tuff or tuff-breccia beds up to $15 \mathrm{~m}$ thick. Normal grading is present in some lapilli-tuff and tuff-breccia beds (fig. 3), but most are ungraded. The lower surfaces of the beds do not appear erosional. Sorting seems poor to very poor (fine ash to large boulders) but could not be quantified. In general, the upper and lower surfaces of the beds are flat and the layers can be followed laterally for several hundred meters or more without pinching out.

These lapilli-tuffs and tuff-breccias contain a mix of dense to poorly vesicular basaltic lapilli and blocks (with glassy basalt dominant over finely crystalline basalt, except in some block-rich and basaltrich layers), Beacon sedimentary rock lapilli and blocks, and an ash-grade matrix composed principally of detrital quartz derived from Beacon sandstones, plus glassy basalt shards (fig. 6). Rare rounded to sub-rounded, unfoliated granitoid clasts up to about $70 \mathrm{~cm}$ in diameter are observed, but most are $<15 \mathrm{~cm}$ in diameter. Different varieties of granitoid fragments can sometimes be found in the same layer. Coarse-grained mafic igneous fragments ("dolerite") are also locally present, and range in size to several decimeters. Finally, composite (recycled peperite) clasts are present in variable, but generally low, amounts.

Proportions of the different components vary between layers (as shown on the stratigraphic sections), and the beds can be broadly classified into the same component associations (subfacies) as the non-bedded, vent-filling deposits at Coombs Hills (Ross 2005; Ross and White submitted): heterolithologic ( $\left.\mathrm{LT}_{\mathrm{h}}\right)$, basalt-rich $\left(\mathrm{TB}_{\mathrm{j}}\right)$, raggy $\mathrm{LT}_{\mathrm{h}}$, and Beacon-rich $\left(\mathrm{LT}_{\mathrm{a}}\right)$, in decreasing bed abundance (figs. 3-5, table 1). Raggy layers occur near the tops of several sections. $\mathrm{LT}_{\mathrm{a}}$ layers are the least common, and include the "gray layer", occurring in stratigraphic sections 1 and 2, and also southwest of Ballance Peak. Field clast counts indicate that the blocklapilli-ash partitioning and the componentry of $\mathrm{LT}_{\mathrm{h}}$ layers is almost identical to mean values for $\mathrm{LT}_{\mathrm{h}}$ deposits in the Coombs Hills vent complex (Ross 2005).

One significant difference when comparing the thick layers at Allan Hills with the non-bedded rocks at Coombs Hills is with the $\mathrm{TB}_{\mathrm{j}}$ facies. Photographs (e.g., fig. 6c) and field clast counts demonstrate that basaltrich layers at southern Allan Hills contain far fewer composite clasts (actually, none in clast counts) and many more fragments of dark brown, finely crystalline basalt. Also, some $\mathrm{TB}_{\mathrm{j}}$ layers contain a countable proportion of cement, whereas the average was zero at Coombs Hills. Finely crystalline basalt clasts are also more abundant in $\mathrm{LT}_{\mathrm{h}}$ and $\mathrm{LT}_{\mathrm{a}}$ layers at Allan Hills than in their equivalents at Coombs Hills.

Some level of clast alignment and imbrication is observed in $\mathrm{LT}_{\mathrm{a}}$ and raggy layers, which contain tabular or elongate clasts. Measurements of aligned clasts were possible at three sites where vertical or overhanging faces are exposed, with clasts sticking out. The inferred transport directions based on these measurements are shown on figure 7 and discussed below.

Facies 2: fine lapilli-tuff or tuff beds. Rare layers of fine lapilli-tuff and tuff are present among the thick-layer facies association, especially near the top of the stratigraphic sections and under block-rich layers (figs. 3-5). These fine-grained layers can be up to $1 \mathrm{~m}$ thick and belong to the thick-layer association, as opposed to thinner, tuff ring-style layers discussed in a following section under "thin volcaniclastic layers" (see also table 1). Some tuff layers display low-angle crosslamination, but this feature is rare. Most beds of fine lapilli-tuff or coarse tuff are internally structureless or display plane-parallel lamination. In some cases, the contact between the fine layers and the underlying beds of lapilli-tuff is gradational, with normal grading in the upper part of the underlying lapilli-tuffs (not shown on sections). 
Some of these fine layers show well-developed vertical lapilli pipes (fig. 8). These pipes are characterized by depletion of fines and enrichment in lapilli relative to the surrounding material, and seem to originate within the fine-grained beds, near their bases.

Facies 3: block-rich layers. The term "blockrich layer" is here restricted to beds with over $15 \%$ blocks that are sandwiched in volcaniclastic deposits with much lower block concentrations. Tuff-breccia layers not sandwiched in block-depleted horizons are excluded (they belong to facies 1). Block-rich layers at southern Allan Hills are of two types: laterally continuous $(\mathrm{km})$ and laterally discontinuous (m to $10 \mathrm{~s}$ of m). Block-rich layers $\mathrm{AH}-1$ to $\mathrm{AH}-4$ are the most extensive and were followed as much as possible for thickness and clast size measurements (figs. 9, 10). The basal contact of block-rich layers is always very sharp and characterized by a sudden increase in the proportion of blocks relative to that of the underlying bed, but not necessarily a change in the composition of the lapilli and ash fraction. The upper contact is somewhat less sharp, often being characterized by a gradual transition, over several decimeters, into a coarse lapilli-tuff with fewer blocks $(<15 \%)$. Layers AH-1 to AH-4 are not graded, but sometimes certain types of blocks are more abundant in the lower or upper portions of some layers, regardless of block size. For example, Beacon Supergroup clasts may be more abundant in the middle and upper portion of a specific layer, with more dense, finely crystalline basalt blocks near the bottom. However, such features are not very continuous along strike, and the layer thickness, amount of blocks, proportion of different block types, and their vertical arrangement changes laterally over tens of meters (sometimes less). Furthermore, some block-rich layers (particularly AH-2) locally "split" into two block-rich layers separated by a few decimeters of block-poor lapilli-tuff. Table 2 gives more details for each layer, figures 9-10 show isopach and isopleths, and figure 11 shows several field photographs.

Other block-rich layers cannot be traced laterally for more than a few tens of meters. Most of these laterally discontinuous layers are thinner than $50 \mathrm{~cm}$, but a couple in the saddle area are several meters thick. One shows coarse-tail normal grading and is rich in large rounded glassy basalt clasts (fig. 11f).

The bases of the thickest block-rich layers (AH1, $\mathrm{AH}-3, \mathrm{AH}-4$, and the two discontinuous ones just mentioned) are often undulating rather than flat (figs. 9e, 9f). The undulations occur on a meter scale and seem to be caused mostly by large bombs and blocks penetrating the underlying layers, which often are fine-grained (fine lapilli-tuffs or coarse tuffs). In contrast, the tops of the same layers are rather flat.

Facies 4: accretionary lapill-bearing layers. Layers containing accretionary lapilli are important in primary volcaniclastic deposits as they can provide both marker horizons for stratigraphic correlations and information on the intensity of the eruption(s) that formed them (Gilbert and Lane 1994). Sites where welldocumented accretionary lapilli-bearing layers occur at southern Allan Hills are listed in table 3 and illustrated in figure 12 .
Facies association: thin volcaniclastic layers. Underlying the thick volcaniclastic layers in many places are deposits, at least $10 \mathrm{~m}$ in total thickness, comprising relatively thin (a few $\mathrm{mm}$ to a few $\mathrm{dm}$ ), well-defined layers, generally at elevations of less than $2095 \mathrm{~m}$ a.s.l. (except for the southernmost occurrence of fig. 2, in an area where subsequent tilting and faulting may have occurred). Thin layers cover less than $15 \%$ of the mapped area, with the best and most extensive outcrops occurring in "Tuff Ring Valley" and the saddle area (fig. 2). In "Tuff Ring Valley", thin layers consist mainly of coarse tuff and fine lapilli-tuff, with occasional beds of fine tuff and coarse lapilli-tuff. Bomb sags are present in some coarse layers, and a few of these sags can be used to infer transport directions (generally from the NW or NNW). Most layers display planar-parallel lamination, but some show low-angle cross-bedding typical of surge deposits. Generally the ratio of juvenile (basaltic) to accidental (Beacon Supergroup sedimentary rock) lapilli lies between $2: 1$ and 4:1.

Apart from "Tuff Ring Valley", other locations where thin layers are found include (i) interbedded with thick layers in the lower part of stratigraphic section 3A; (ii) in a small area east of Ballance Peak; (iii) elsewhere in southernmost Allan Hills. These small outcrops cannot be shown at the scale of figure 2 and they were not mapped in sufficient detail to show on a larger scale map.

Facies association: non-bedded, basalt-rich, poorly sorted tuff-breccia and coarse lapilli-tuff $\left(T B_{j}\right)$ bodies. The characteristics of these bodies, which have crosscutting relationships with the layers, are presented in table 4.

\section{Interpretation}

Previous investigators did not separate the Mawson Formation into two members at Allan Hills, or consider that different parts of the formation could have different origins: all published interpretations refer to the whole of the Mawson and propose an origin as "mudflows" (Ballance and Watters 1971), "volcanic mudflows and explosion breccias" (Grapes et al. 1974), or "lahars" (Elliot and Hanson 2001). Here we discuss what we think is the most likely origin for each lithofacies and facies association.

Facies association: thick volcaniclastic layers. Different lithofacies occuring together within this association are interpreted to have distinct origins, and so are discussed separately. One point the facies have in common, however, is that we infer that they were all produced by pyroclastic density currents (PDCs) of variable volume, particle concentration, temperature, moisture level, and travel distance - in some cases accompanied by simultaneous ballistic fall. No pure pyroclastic fall deposits can be convincingly demonstrated.

Facies 1: poorly sorted, coarse lapilli-tuff or tuff-breccia beds. Many thick lapilli-tuff and tuffbreccia beds, taken individually and out of context, could indeed be interpreted as lahar deposits (cf. references above) because they contain very large fragments, have a poor or very poor sorting, and display weakly developed fabrics (Fisher and Schmincke 1984; Vallance 2000). 
Similar characteristics are also seen in the deposits of high-concentration PDCs, as well as some glacial and fluvial deposits. A fluvial origin can be excluded given the very poor sorting, and the lack or scarcity of rounded clasts, high-angle cross beds, channelling, or erosional lower contacts; a glacial origin can be excluded based on the lack of abundant clay-grade matrix, faceted or rounded clasts, erosional lower contacts, or striated bedrock (Fisher and Schmincke 1984). Also, unbroken raggy juvenile fragments and accretionary lapilli seem unlikely in glacial or fluvial deposits (although see Boulter 1987 regarding the a.1.). Finally, a relatively warm climate for Antarctica in the Jurassic is indicated by dinosaur fossils and other features (J.W. Collinson, pers. commun. 2002), arguing against the possibility of glaciers.

The presence of unbroken rags and accretionary lapilli in the sequence, suggests that most, if not all, the thick lapilli-tuff/tuff-breccia layers are the deposits of PDCs rather than lahars, an interpretation given further, indirect, support by evidence for ballistic emplacement of blocks in the block-rich layers (see below). In addition, these components suggest that relatively concentrated PDCs, capable of keeping lapilli-size rags at plastic temperatures during transport, entrained coolformed accretionary lapilli before layer deposition took place.

The clast assemblage of $\mathrm{LT}_{\mathrm{h}}-$ the most common lithofacies in both the Coombs Hills vent complex and the thick-layer facies association at southern Allan Hills - supports inferences of phreatomagmatic eruptions (White and McClintock 2001; McClintock and White 2005; Ross and White submitted). Other subfacies in the thick layers are also interpreted as phreatomagmatic deposits. The concentrated PDCs inferred to have deposited the thick layers probably formed during the collapse of phreatomagmatic eruption columns having moderate magma-water ratios (Koyaguchi and Woods 1996) - this is consistent with the general absence of lateral or vertical transitions of these layers into finer, betterstratified facies.

On the other hand, one can imagine that the concentrated PDCs represent the proximal, overloaded portions of dry $\left(>100^{\circ} \mathrm{C}\right)$ base surges. Dry base surges are generally thought of as turbulent, overall dilute, currents, but near the vent, they are in part relatively high-concentration, overloaded currents that rapidly deposit material from suspension via a dense lower zone to produce structureless or disorganized beds (Valentine 1987; Sohn and Chough 1989; White 1991). Laterally, such beds typically grade into crudely stratified units or even dune-bedded deposits more typical of dilute currents, i.e. the particle concentration decreases and the role of traction increases in the current (Sohn and Chough 1989). In tuff ring settings, the structureless beds only extend a few hundred meters (or less) away from the vent, but surge deposits from sub-Plinian to Plinian eruptions can perhaps have a run-out of up to $10 \mathrm{~km}$ (Valentine and Fisher 2000), suggesting that powerful surge-generating eruptions could, in theory, deposit thick structureless beds a few kilometers away from the vent - this might apply to southern Allan Hills.
Overloading of base surges near the vent, with rapid deposition of material in excess of current capacity, is in a way similar to the rapid "load-dumping" of collapsing Plinian columns to form "lag-breccias" that grade laterally into more typical ignimbrites (Wright and Walker 1977; Walker 1984; White and Schmincke 1999).

One important characteristic of the thick coarse lapilli-tuff and tuff-breccia layers studied at southern Allan Hills, apart from their composition, texture, bedding features and thicknesses (which suggest they represent PDC deposits), is that they form uninterrupted piles up to $30 \mathrm{~m}$ thick, with up to five similar beds stacked on top of one another. There is no evidence for significant time gaps between deposition of these layers (erosion surfaces, epiclastic beds, reworking by water or wind, etc.), so they must have been emplaced in relatively quick succession. Extremely variable transport directions for different layers (see below) suggest that more than one vent was involved over time. Low thinning rates suggest relatively distant source vents, and hence vent locations beyond the present Allan Hills outcrop areas.

As already mentioned, the relative abundance of different lapilli-tuff and tuff-breccia facies $\left(\mathrm{LT}_{\mathrm{h}}, \mathrm{TB}_{\mathrm{j}}\right.$, $\mathrm{LT}_{\mathrm{a}}$, raggy $\mathrm{LT}_{\mathrm{h}}$ ) is similar in the Coombs Hills vent complex and in the thick layers of southern Allan Hills. Further, at least the "gray layer" could plausibly, on the basis of general componentry and inferred flow directions (see below), have been derived from Coombs Hills. The detailed componentry of the individual facies, and the clast shapes, are also remarkably similar at the two locations. One exception is the basalt-rich layers, which contain far more crystalline basalt fragments, and far fewer composite clasts, than $\mathrm{TB}_{\mathrm{j}}$ zones in the Coombs Hills vent complex or $\mathrm{TB}_{\mathrm{j}}$ zones under the layers of southern Allan Hills.

Specific evidence of current directions in the layers themselves is scarce. Paleocurrent measurements based on aligned clasts are available for three sites as explained above. Generally in ignimbrites, the local flow direction does not directly indicate direction toward source because of the tendency of PDCs to follow topography (Ui et al. 1989; Freundt et al. 2000). Further, vortices in the flowing mass can produce apparent orientations which are significantly different than the overall flow direction (Baer et al. 1997). Given this background, it is perhaps not surprising that sites (a) and (b), both in the "gray layer" and located only a few hundred meters apart, give paleocurrent orientations differing by about $80^{\circ}$ (fig. 7). The average of the two paleocurrent orientations points directly away from Coombs Hills, so the data are permissive of a source for the "gray layer" there. Site (c), for a $\mathrm{LT}_{\mathrm{a}}$ layer under block-rich layer $\mathrm{AH}-1$, indicates transport from the southwest or south. No $\mathrm{LT}_{\mathrm{a}}$-emitting vents are known from that direction, although vents could be buried beneath younger Jurassic layers, or hidden by the present-day ice cover. Alternatively, the measured local flow orientation might not be representative: if one allows for local changes in current direction, then the source of this particular layer could also be Coombs Hills. 
Facies 2: fine lapilli-tuff or tuff beds. The rare beds of tuff or fine lapilli-tuff could be from pyroclastic fall or dilute density current deposition. The latter origin is supported by rare examples of wavy, low-angle crosslamination, and gradational contacts with underlying coarser layers.

Facies 3: block-rich layers. It appears very unlikely that the thick and very extensive block-rich layers (AH-1, AH-3, AH-4) are lahar deposits, because some contain unbroken "rags", and volcanic bombs at their base pierce underlying layers. These laterally continuous block-rich layers, and also the thick discontinuous ones in the saddle area, had a ballistic component as indicated both by the irregularity of their lower surfaces, and by uncommon distinct impact sags. Ballistic fall of large blocks and bombs, and high thinning rates, suggest local $(<<5 \mathrm{~km})$ sources. A lateral component in the transport system (i.e., a pyroclastic flow component) is also demonstrated by entrainment of accretionary lapilli (derived from the underlying bed) in AH-4.

Given the lateral and vertical variations in componentry and the evidence for specific layers "splitting" in two, it is probable that some block-rich "layers" represent composite features consisting of lenses that overlap at specific stratigraphic levels. To the extent that the layers are indeed composite, whole-layer thinning or grainsize maps will be telling a complex story, which makes it easy to understand why they don't provide tidy isopach and isopleth maps pointing to clear (single) source sites. In AH-1, rapid thinning and the very large size of some clasts is suggestive of a very proximal source (or sources), but the combined isopach and isopleth patterns are inconclusive regarding direction to source. Bomb sags in AH-1 are not sufficiently asymmetric to be used for estimation of transport direction. For AH-2, thinning of the layer towards the north on Dionysus Hill (fig. 9, lower left) might indicate transport from the south, but the thickness patterns are not particularly convincing. Isopachs and isopleths for AH-3 suggest that the Dionysus Hill area is more proximal than the unnamed hill to the southwest. Generally, thickness patterns are compatible with a proximal source or sources to the north or northwest, in the area where cross-cutting $\mathrm{TB}_{\mathrm{j}}$ bodies crop out (fig. 2). Finally, for AH-4, the isopachs and isopleths are particularly inconclusive with regard to the source area or transport direction, but one might speculate that crosscutting $\mathrm{TB}_{\mathrm{j}}$ bodies in the saddle area could indicate the vent sites for AH-4, with perhaps another simultaneously operating(?) vent to the south. So the four layers for which thickness and maximum clast size information was collected each seem to have originated from different local vents or source areas.

The thick, discontinuous (unlabelled) block-rich layers in the saddle area are probably very proximal eruption products, with possible vent sites suggested by cross-cutting $\mathrm{TB}_{\mathrm{j}}$ bodies just north of the saddle (not shown on fig. 2).

Facies 4: accretionary lapilli-bearing layers. Beds containing rim-type accretionary lapilli belong to the thick-layer facies association, although the beds in which they are most highly concentrated are actually quite thin (a few dm; see table 3). It is not possible on the basis of available data to decide if these beds, with up to $50 \%$ accretionary lapilli, are fall or PDC deposits. In beds containing only a few percent accretionary lapilli, they are dispersed throughout the bed, rather than concentrated near the base (for fall deposits) or the top (for PDC deposits) as reported by Schumacher and Schmincke (1991). Furthermore, one of these relatively thick beds with only a few percent accretionary lapilli also contains raggy basaltic clasts that provide evidence for hot-clast emplacement (fig. 12a). According to Schumacher and Schmincke (1995), accretionary lapilli form "in turbulent ash clouds when particles carrying liquid films of condensed moisture collide with each other". Liquid water indicates relatively cool temperatures $\left(<100^{\circ} \mathrm{C}\right)$ for the transport system in which the accretionary lapilli formed, which indicates that products of two distinct transport systems were mixed together to produce a deposit in which "rags" co-exist with them.

Generally, accretionary lapilli-bearing layers at southern Allan Hills cannot be followed laterally for more than about $1 \mathrm{~km}$, and so cannot be used for correlations between sections and cannot be said to be very widely dispersed. Some of this apparent lack of wide dispersal might be due to erosion of accretionary lapilli-bearing layers by subsequent PDCs as suggested by local 'pods' of accretionary lapilli found at the base of some thick layers. Such evidence for partial erosion of these layers seriously limits their utility in reconstructing the eruption dynamics (height of the eruption plume, etc.). Nevertheless, the large size of the accretionary lapilli and their multiple rims are evidence for repeated passage of lapilli in eruption clouds. We infer that these formed in highly turbulent, probably only locally developed, transport systems; the most likely such systems are dilute (enough to be highly turbulent) density currents, either independent surges, or co-PDC ash clouds.

Thick-layer association: overall eruption characteristics. The style of eruption represented by the thick layers of coarse lapilli-tuff or tuff-breccia with their associated or included accretionary lapilli remains poorly constrained because limited outcrop has not allowed thinning trends to be quantified for the depositional units (except for the block-rich layers in the same sequence).

If we accept, for the sake of argument, that some of the meters-thick beds of coarse lapilli-tuff or tuffbreccia were erupted from the Coombs Hills vent complex, roughly centered $10 \mathrm{~km}$ west of Allan Hills, then individual PDCs flowed at least on the order of $10 \mathrm{~km}$ from source. If deposit distribution were roughly circular then the areal distribution could have been larger than $300 \mathrm{~km}^{2}$, with a hypothetical $5 \mathrm{~m}$ mean-thickness bed representing over $1.5 \mathrm{~km}^{3}$ of material (for a single PDC deposit). Despite uncertainty regarding precise volumes and thinning rates, it is clear that these are very large-volume pyroclastic deposits compared with those formed by common basaltic phreatomagmatic eruptions of tuff cones and rings. We have inferred a strong phreatomagmatic component to the eruptions, coupled with emplacement of dense hot-clast bearing PDCs and 
co-PDC accretionary lapilli formation. The implied style of eruption is one in which thermally heterogeneous material is rapidly dispersed from a dense and generally warm, damp eruption plume by gravitational spreading. Cool-formed accretionary lapilli were probably produced in the dilute upper reaches of the spreading currents, then somehow re-entrained into the dense currents, just prior to deposition.

Thick and voluminous layers are not the product of relatively small-volume, short-lived eruption bursts typical of diatremes. Instead, the eruptions had to be more sustained so that enough material could come out of the vents - for example, $1 \mathrm{~km}^{3}$ of $2.0 \mathrm{~g} / \mathrm{cm}^{3}$ material (a plausible approximate value for the final PDC deposits if the solid density was $2.5 \mathrm{~g} / \mathrm{cm}^{3}$ and the porosity 20\%) takes over 55 hours to come out at a mass eruption rate of $10^{7} \mathrm{~kg} / \mathrm{s}$, over 5.5 hours at $10^{8} \mathrm{~kg} / \mathrm{s}$, etc. [These numbers are given for illustrative purposes only.] That groundwater could be supplied to explosion sites in sufficient amounts to maintain such a large phreatomagmatic eruption for such a long time might seem surprising, but this is the natural conclusion from our analysis - the problem is lessened by taking into account the suggestion of White and McClintock (2001) that recycling of water, as well as pyroclasts, might be important in the vents.

Other lithofacies and associations. We infer that the thin volcaniclastic layers were mostly deposited by dilute PDCs and pyroclastic fall (see Ross 2005 for more details on these). The non-bedded basalt-rich tuff-breccia or lapilli-tuff $\left(\mathrm{TB}_{\mathrm{j}}\right)$ bodies invaded existing volcaniclastic deposits, and associated domains of peperite and coherent basalt suggest weakly energetic (mostly non-explosive) magma-wet 'sediment' interaction, where the 'sediment' consisted of other volcaniclastic deposits (again, see Ross 2005 for a more complete argument).

Relationships between the thick layers, thin layers, and non-bedded $\mathbf{T B}_{j}$ zones. Thin layers occur dominantly beneath, but are locally interbedded with, the thick volcaniclastic layers in southern Allan Hills (e.g, cross-section $\mathrm{Y}^{-\mathrm{Y}^{\prime}}$ and stratigraphic section $3 \mathrm{~A}$ ). The local interbedding of thin layers among thick layers suggests that the two styles of activity partly overlapped in time, although during the later stages, eruptions forming thick layers appear to have dominated. All types of layers were formed as a result of phreatomagmatic activity, and probably deposited at least in part by PDCs. Some thick and thin layers could, at least in part, have been derived from the same vents. Other thick beds, notably the "gray layer", are not of local derivation, as indicated by paleocurrent measurements, and a lack of suitable Beacon-rich "vent" sites (i.e., Beacon-rich diatremes) in southern Allan Hills.

All these layers are topographically above nonbedded $\mathrm{TBj}$ rocks, and one might suggest that the layers therefore stratigraphically overlie non-bedded rocks, in the same way that a layered sequence grades downwards into the Coombs Hills vent complex (McClintock and White 2005). Further, the composition of the thick volcaniclastic layers at Allan Hills is compatible with a derivation from Coombs Hills-style vents, some of which (at least some basalt-rich ones) have to be located near the points of maximum thickness in the major block-rich layers; this also supports the idea that a Coombs Hills-style vent complex might exist locally (Elliot et al. 2003, 2004). Although the idea is plausible, and is not ruled out entirely on the basis of observed outcrop relationships, there exist at least three counterarguments.

First, the nature of the vertical transition between non-bedded and layered volcaniclastic deposits at the two sites is different. At Coombs Hills, diffuse layering appears progressively upwards in the nonbedded rocks, and is manifest as poorly defined subhorizontal concentrations of block-sized clasts, eventually replaced by obvious layering planes (McClintock and White 2005). $\mathrm{TB}_{\mathrm{j}}$ zones invading layered volcaniclastic rocks are not observed at Coombs Hills. In contrast, in key outcrops at both southern and central Allan Hills, steep to sub-vertical contact relationships are observed between non-bedded $\mathrm{TB}_{\mathrm{j}}$ zones and sub-horizontally layered volcaniclastic rocks, demonstrating that at least these particular $\mathrm{TB}_{\mathrm{j}}$ zones crosscut, and hence are younger than, the layers.

Secondly, Mawson-Beacon contacts in central Allan Hills are clearly sub-horizontal to gently sloping (Ballance and Watters 1971; Reubi et al. 2005); by contrast, the margins of the Coombs Hills vent complex are inferred to be steep (White and McClintock 2001). Also in central Allan Hills, as already alluded to, the $\mathrm{m}_{1}$ member of the Mawson Formation, resting directly on eroded Beacon Supergroup, is inferred to have been deposited by lateral flow of a debris avalanche towards the northeast, into a topographic depression (Reubi et al. 2005). In southern Allan Hills, Mawson-Beacon contacts are nowhere exposed, and it is not known if $\mathrm{m}_{1}$ occurs at depth. Nevertheless, in the absence of evidence to the contrary, it can be supposed that the paleo-topographic depression in central Allan Hills extended southwestwards, and that the $\mathrm{m}_{2}$ volcaniclastic layers, both thick and thin, essentially filled this depression.

Finally, at Coombs Hills, north of Mt Brooke the Mawson Formation has characteristics typical of diatremes, such as (i) multiple steep to vertical crosscutting zones of poorly sorted, non-bedded volcaniclastic material with different compositions, (ii) steeply dipping Beacon Supergroup rafts and volcaniclastic megablocks, "floating" in poorly sorted, unbedded volcaniclastic material, and (iii) abundant basalt dikes (White and McClintock 2001; McClintock and White 2005); these features are all absent from southern Allan Hills. It is concluded that there is no convincing evidence for a large Coombs Hills-type vent complex anywhere at Allan Hills.

\section{Summary and conclusions}

Mafic volcaniclastic deposits are increasingly recognized as an important component of flood basalt provinces. In the provinces where such deposits are best documented, they are overwhelmingly of hydromagmatic origin. We do not believe that a single emplacement model can apply to all mafic volcaniclastic deposits in all flood basalt provinces, and even within single provinces, a great variety of deposits exists. In the Mawson Formation of the Ferrar large igneous province, for 
instance, within a relatively small region one can find the deposits of a basalt-poor debris avalanche, emplaced into a pre-existing topographic depression (member $\mathrm{m}_{1}$ at central Allan Hills; Reubi et al. 2005); thick, mostly basalt-rich, volcaniclastic layers formed by pyroclastic density currents (PDCs), possibly within the same depression (member $\mathrm{m}_{2}$ at southern Allan Hills; fig. 13), and steep, mutually cross-cutting, non-bedded zones of (mostly basalt-rich) volcaniclastic rock forming a vent complex (Coombs Hills; White and McClintock 2001; Ross 2005; McClintock and White 2005). This paper has focused on southern Allan Hills because the thick, laterally continuous layers exposed there have not been reported from elsewhere in the Ferrar province; these deposits also represent the best known example of largescale, mafic, primary pyroclastic layers from any continental flood basalt province.

The southern Allan Hills thick-layer association contains four facies: (1) poorly sorted, coarse lapilli-tuff or tuff-breccia beds; (2) tuff or fine lapilli-tuf beds; (3) block-rich layers; (4) accretionary lapilli-bearing layers. Some of the layers of the volumetrically dominant facies (1) could represent lahar deposits, but we prefer an interpretation as PDC deposits based on the nature of the overall succession, and especially on the presence of 'raggy' clasts of glassy basalt that provide evidence for emplacement of hot, plastic clasts in several beds. From the poor sorting and internally structureless character of the facies (1) layers it can be deduced that the PDCs had a high particle concentration, and probably formed by collapse of phreatomagmatically generated eruption plumes. By analogy with tuff ring deposits, these concentrated PDCs could have become dilute ('surges') in their distal portions, after most of the particle load had been dumped. Such dilute currents, perhaps from less voluminous plumes, are inferred to have deposited the type (2) layers. Laterally continuous block-rich layers, several meters in thickness, had a ballistic fall component; the layers appear, on the basis of the huge blocks and bombs piercing the underlying layers, to have been derived from (multiple) nearby vents.

Among type (1) layers, the proportions of the different subfacies (basalt-rich, heterolithologic, Beaconrich, raggy, etc.) are similar to those in the Coombs Hills vent complex. The detailed componentry and particle size distribution of individual subfacies is also strikingly similar to those at Coombs Hills. These observations suggest that Coombs Hills-type vents are a plausible source for these layers. Nevertheless, although some local vents are suggested for the block-rich layers, a Coombs Hills-type complex probably does not exist right under Allan Hills.

Rim-type accretionary lapilli are present in various beds from the thick-layer association (facies 4). The largest accretionary lapilli, up to $4.5 \mathrm{~cm}$, form up to $50 \%$ of a $10 \mathrm{~cm}$-thick bed on the western side of Bacchus Hill, but are absent from other sections. These lapilli probably were recycled through eruption clouds several times and hence cannot be used to constrain the thickness of the clouds. Erosion of accretionary lapillibearing layers by subsequent PDCs also complicates the story.
The thick layers of southern Allan Hills are underlain by, and locally interstratified with, thinner tuff ring-style layers. These thin layers are likely to represent base surge deposits, and some or all may have originated from local vents. Non-bedded, poorly sorted basalt-rich tuff breccias and lapilli-tuffs $\left(\mathrm{TB}_{\mathrm{j}}\right)$ bodies are present at low elevations, topographically below the layered part of $m_{2}$. Cross-cutting relationships indicate that the $\mathrm{TB}_{\mathrm{j}}$ zones are at least partly invasive into, and hence younger than, the layers. Features typical of diatremes which are present at Coombs Hills are missing from southern Allan Hills, and there is evidence for erosion of the Beacon sequence in central Allan Hills, suggesting that the Mawson formation was deposited in a pre-existing topographic depression rather than a phreatocauldron.

\section{Acknowledgements}

Our work at Allan Hills was supported by Antarctica New Zealand, the University of Otago, and a $\mathrm{PhD}$ scholarship to Ross from the Fonds de recherche sur la nature et les technologies (Quebec, Canada). John Cottle served faithfully as field guide. We thank Olivier Reubi for field help and discussions, Alan F. Cooper for encouragement, G. Valentine and, especially, Y.K. Sohn, for useful pre-submission reviews, plus L. Mastin and G. Heiken for helpful journal reviews.

\section{References cited}

Baer, E. M., Fisher, R. V., Fuller, M., and Valentine, G. 1997. Turbulent transport and deposition of the Ito pyroclastic flow: Determinations using anisotropy of magnetic susceptibility. J. Geophys. Res. 102:22,565-22,586.

Ballance, P. F., and Watters, W. A. 1971. The Mawson Diamictite and the Carapace Sandstone, formations of the Ferrar Group at Allan Hills and Carapace Nunatak, Victoria Land, Antarctica. N. Z. J. Geol. Geophys. 14:512-527.

Barrett, P. J. 1991. The Devonian to Jurassic Beacon Supergroup of the Transantarctic Mountains and correlatives in other parts of Antarctica. In Tingey, R. J., ed., The Geology of Antarctica. Oxford University Press, Oxford, p. 120-152.

Boulter, C. A. 1987. Subaqueous deposition of accretionary lapilli: significance for palaeoenvironmental interpretations in Achaean greenstone belts. Precambrian Res. 34:231-246.

Elliot, D. H. 1992. Jurassic magmatism and tectonism associated with Gondwanaland break-up: an Antarctic perspective. In Storey, B. C., Alabaster, T., and Pankhurst, R. J., eds., Magmatism and the Causes of Continental Break-up. Geological Society Special Publication 68:165-184.

Elliot, D. H. 2000. Stratigraphy of Jurassic pyroclastic rocks in the Transantarctic Mountains. J. African Earth Sci. 31:7789.

Elliot, D. H. 2002. Paleovolcanological setting of the Mawson Formation: evidence from the Prince Albert Mountains, Victoria Land. In Gamble, J. A., Skinner, D. N. B., and Henrys, R., eds., Antarctica at the close of a millenium. Royal Society of New Zealand Bulletin 35:185-192.

Elliot, D. H., and Hanson, R. E. 2001. Origin of widespread, exceptionally thick basaltic phreatomagmatic tuff breccia in the Middle Jurassic Prebble and Mawson Formations, Antarctica. J. Volcanol. Geotherm. Res. 111:183-201.

Elliot, D. H., Haban, M. A., and Siders, M. A. 1986. The Exposure Hill Formation, Mesa Range. In Stump, E., ed., 
Geological Investigations in Northern Victoria Land. Antarctic Research Series 46:267-278.

Elliot, D. H., Fortner, E., and Elliot, J. A. F. 2003. Mawson Formation at Allan Hills, Antarctica: evidence for a largescale phreatomagmatic caldera [abstract]. Eos 84(46), Fall Meet. Suppl.:Abstract V52G-02.

Elliot, D. H., Fortner, T., and Grimes, C. B. 2004. BeaconMawson field relations at Allan and Coombs Hills, south Victoria Land. In H.-W. Hubberten, ed., Proceedings of the ninth international symposium on Antarctic earth sciences. Postdam (Germany).

Fisher, R. V., and Schmincke, H.-U. 1984. Pyroclastic Rocks. Springer-Verlag, Berlin, $472 \mathrm{p}$.

Freundt, A., Wilson, C. J. N., and Carey, S. N. 2000. Ignimbrites and block-and-ash flow deposits. In Sigurdsson, H., Houghton, B., McNutt, S. R., Rymer, H., and Stix, J., eds., Encyclopedia of Volcanoes. Academic Press, London, p. 581-599.

Gilbert, J. S., and Lane, S. J. 1994. The origin of accretionary lapilli. Bull. Volcanol. 56:398-411.

Grapes, R. H., Reid, D. L., and McPherson, J. G. 1974. Shallow dolerite intrusion and phreatic eruption in the Allan Hills region, Antarctica. N. Z. J. Geol. Geophys. 17:563-577.

Gunn, B. M., and Warren, G. 1962. Geology of Victoria Land between the Mawson and Murlock Glaciers, Antarctica. New Zealand Geological Society Bulletin 71, $157 \mathrm{p}$.

Hanson, R. E., and Elliot, D. H. 1996. Rift-related Jurassic phreatomagmatism in the central Transantarctic Mountains: precursory stage to flood-basalt effusion. Bull. Volcanol. 58:327-347.

Houghton, B. F., Wilson, C. J. N., Fierstein, J., and Hildreth, W. 2004. Complex proximal deposition during the Plinian eruptions of 1912 at Novarupta, Alaska. Bull. Volcanol. 66:95-133.

Koyaguchi, T., and Woods, A. W. 1996. On the formation of eruption columns following explosive mixing of magma and surface-water. J. Geophys. Res. 101:5561-5574.

McClintock, M. K., 2001. Phreatomagmatism at Coombs Hills, Antarctica - Magma-water super-volcanism in a wet, failed rift: Unpub. M.Sc. thesis, University of Otago, 189 p.

McClintock, M. K., and White, J. D. L. 2005. Large-volume phreatomagmatic vent complex at Coombs Hills, Antarctica records wet, explosive initiation of flood basalt volcanism in the Ferrar LIP. Bull. Volcanol. (in press)

McClintock, M. K., Houghton, B. F., Skilling, I. P., and White, J. D. L. 2003. Evolution of a large-volume explosive vent-complex at the base of the Karoo LIP: Sterkspruit Complex, South Africa [abstract]. Eos 84(46) (Fall meeting suppl.):Abstract V52G-05.

Reubi, O., Ross, P.-S., and White, J. D. L. 2005. Debris avalanche deposits associated with large igneous province volcanism: an example from the Mawson Formation, central Allan Hills, Antarctica. Geol. Soc. Am. Bull. (in revision)

Ross, P.-S., 2005, Volcanology of the Mawson Formation at Coombs and Allan Hills, South Victoria Land, Antarctica:
Unpub. PhD thesis, University of Otago, Dunedin, New Zealand, $400 \mathrm{p}$.

Ross, P.-S., and White, J. D. L. 2005. Unusually large clastic dykes formed by elutriation of a poorly sorted, coarsergrained source. J. Geol. Soc. [London] 162:579-582.

Ross, P.-S., and White, J. D. L. submitted. Debris-filled volcanic vent structures in a phreatomagmatic complex at Coombs Hills, Ferrar large igneous province, Antarctica. J. Volcanol. Geotherm. Res.

Ross, P.-S., Ukstins Peate, I., McClintock, M. K., Xu, Y. G., Skilling, I. P., White, J. D. L., and Houghton, B. F. 2005. Mafic volcaniclastic deposits in flood basalt provinces: a review. J. Volcanol. Geotherm. Res., doi:10.1016/j.jvolgeores.2005.02.003

Schumacher, R., and Schmincke, H.-S. 1991. Internal structure and occurrence of accretionary lapilli - a case study at Laacher See Volcano. Bull. Volcanol. 53:612-634.

Schumacher, R., and Schmincke, H.-S. 1995. Models for the origin of accretionary lapilli. Bull. Volcanol. 56:626-639.

Skilling, I. P., Chapman, M. G., and Smellie, J. L. 2001. Terrestrial subice volcanism and pre-flood basalt hydrovolcanism as models for magma-volatile interaction on Mars [abstract]. Eos 82(20):V42A-09 (Spring Meeting Supplement).

Sohn, Y. K., and Chough, S. K. 1989. Depositional processes of the Suwolbong tuff ring, Cheju Island (Korea). Sedimentology 36:837-855.

Stump, E. 1995. The Ross Orogen of the Transantarctic Mountains. Cambridge University Press, Cambridge, 284 p.

Ui, T., Suzuki-Kamata, K., Matsusue, R., Fujita, K., Metsugi, H., and Araki, M. 1989. Flow behavior of large-scale pyroclastic flows - evidence obtained from petrofabric analysis. Bull. Volcanol. 51:115-122.

Valentine, G. A. 1987. Stratified flow in pyroclastic surges. Bull. Volcanol. 49:616-630.

Valentine, G. A., and Fisher, R. V. 2000. Pyroclastic surges and blasts. In Sigurdsson, H., Houghton, B., McNutt, S. R., Rymer, H., and Stix, J., eds., Encyclopedia of Volcanoes. Academic Press, London, p. 571-580.

Vallance, J. W. 2000. Lahars. In Sigurdsson, H., Houghton, B., McNutt, S. R., Rymer, H., and Stix, J., eds., Encyclopedia of Volcanoes. Academic Press, London, p. 601-616.

Walker, G. P. L. 1984. Origin of coarse lithic breccias near ignimbrite source vents. J. Volcanol. Geotherm. Res. 25:157-171.

White, J. D. L. 1991. Maar-diatreme phreatomagmatism at Hopi Buttes, Navajo Nation (Arizona), USA. Bull. Volcanol. 53:239-258.

White, J. D. L., and Schmincke, H.-U. 1999. Phreatomagmatic eruptive and depositional processes during the 1949 eruption on La Palma (Canary Islands). J. Volcanol. Geotherm. Res. 94:283-304.

White, J. D. L., and McClintock, M. K. 2001. Immense vent complex marks flood-basalt eruption in a wet, failed rift: Coombs Hills, Antarctica. Geology [Boulder] 29:935-938

Wright, J. V., and Walker, G. P. L. 1977. The ignimbrite source problem: significance of a co-ignimbrite lag-fall deposit. Geology [Boulder] 5:729-732. 
Table 1. Organization of Mawson Rock Types into Facies Associations, Facies and Subfacies at Southern Allan Hills

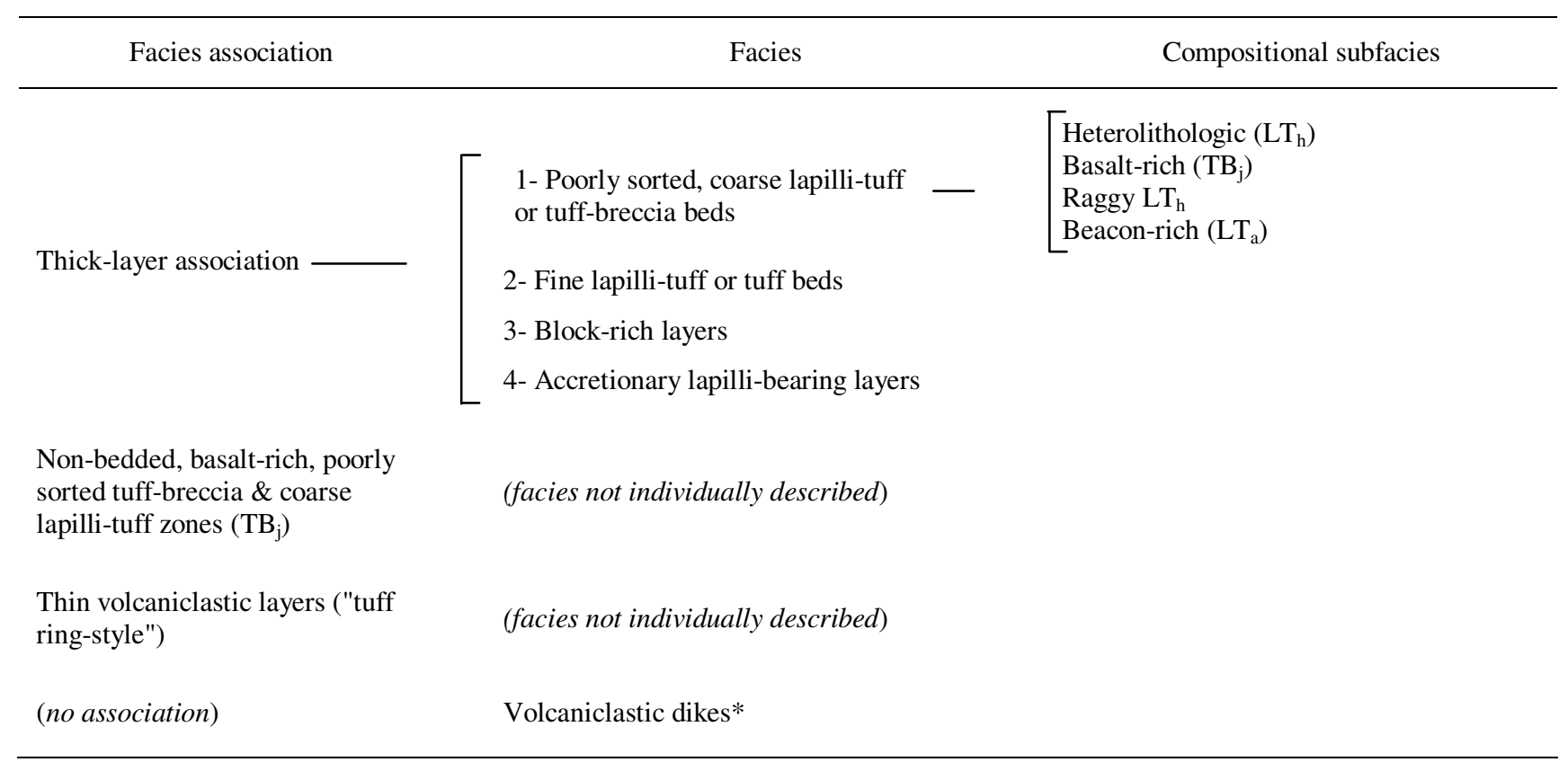

* Not discussed in this paper, see Ross and White (2005).

Table 2. Summary of Important Laterally-Continuous Block-Rich Layers

\begin{tabular}{|c|c|c|c|c|}
\hline Layer & $\begin{array}{l}\text { Thickness } \\
\text { range }(\mathrm{m}) ; \\
\text { isopach } \\
\text { trends }\end{array}$ & $\begin{array}{l}\text { Isopleth range } \\
(\mathrm{cm}) ; \text { trends }\end{array}$ & Layer description & Comments \\
\hline AH-1 & $\begin{array}{l}2-5 \\
\text { thinning } \\
\text { towards } \\
\mathrm{N} \text { or } \mathrm{NW}\end{array}$ & $\begin{array}{l}57-290 ; \\
\text { higher values } \\
\text { towards NNE }\end{array}$ & $\begin{array}{l}15 \% \text { blocks; overall, glassy basalt frags \& composite clasts more abundant than } \\
\text { finely crystalline basalt fragments. Very few Beacon blocks. Lapilli fraction } \\
\text { accounts for } \sim 40 \% \text { of rock \& is } \mathrm{LT}_{\mathrm{h}} \text {-like, i.e. glassy basalt clasts dominate over } \\
\text { Beacon clasts. Among Beacon lapilli, lithologies are fine sst, medium sst, } \\
\text { siltstone, carbonaceous mudstone \& coal in decreasing proportions }\end{array}$ & $\begin{array}{l}\text { AH-1 lies in middle of } \\
35 \text { m-thick succession } \\
\text { of } \mathrm{LT}_{\mathrm{h}} \text { layers ( see } \\
\text { stratigr. section } 2 \text { ) }\end{array}$ \\
\hline AH-2 & $0.3-2.5 *$ & $14-43$ & $\begin{array}{l}15-30 \% \text { blocks, locally } \leq 50 \% \text {. Generally, blocks of Beacon sst dominate over } \\
\text { finely crystalline basalt, w/ only rare glassy basalt (fig. } 11 \mathrm{~d} \text { ). Locally, blocks of } \\
\text { finely crystalline basalt predominate, especially when total proportion of blocks } \\
\text { is high. Lapilli fraction has } \mathrm{LT}_{\mathrm{a}} \text { composition like the sandwiching layers, w/ } \\
\text { Beacon clasts dominant over glassy basalt clasts }\end{array}$ & $\begin{array}{l}\text { Directly overlies "gray } \\
\text { layer" }\end{array}$ \\
\hline AH-3 & $\begin{array}{l}1-8 ; \text { max. } \\
\text { on } \\
\text { Dionysus } \\
\text { Hill }\end{array}$ & $\begin{array}{l}42-110 \\
\text { largest clasts } \\
\text { occur where } \\
\text { layer is } \\
\text { thickest }\end{array}$ & $\begin{array}{l}\text { 35-65\% blocks, w/ dense, angular finely crystalline basalt generally dominant } \\
\text { over glassy basalt \& composite clasts; only rare Beacon blocks (fig. 11c). One } \\
\text { unfoliated pink granite clast } 70 \mathrm{~cm} \text { across; a few rounded dolerite fragments } \leq 50 \\
\mathrm{~cm} \text { across. Lapilli fraction generally } \mathrm{LT}_{\mathrm{h}} \text {-like, locally w/ some raggy basaltic } \\
\text { clasts. Rags also present in lapilli-tuff layers above \& below AH-3 (fig. } 4 \text { ) }\end{array}$ & \\
\hline AH-4 & $\begin{array}{l}0.6-3 ; \text { no } \\
\text { clear } \\
\text { trend }\end{array}$ & $\begin{array}{l}32-124 ; \\
\text { largest clasts } \\
\text { to the NE }\end{array}$ & $\begin{array}{l}\text { 15-35\% blocks, generally mostly glassy basalt \& composite clasts w/ subordinate } \\
\text { amounts of angular, dense, finely crystalline basalt blocks (fig. } 11 \mathrm{e} \text { ). One granite } \\
\text { clast } 50 \mathrm{~cm} \text { across. Locally crystalline basalt blocks dominate over glassy basalt } \\
\text { frags \& composite clasts, particularly on E side of Bacchus Hill. Rare Beacon } \\
\text { blocks. Lapilli fraction is } \mathrm{LT}_{\mathrm{h}} \text {-like, w/ some rags; base of AH-4 locally contains } \\
\text { accretionary lapilli (on W side of Bacchus Hill only) }\end{array}$ & $\begin{array}{l}\text { Prominent block-rich } \\
\text { layer on Bacchus Hill } \\
\text { (fig. 11d); was noted by } \\
\text { Gunn \& Warren (1962, } \\
\text { p. 119) }\end{array}$ \\
\hline
\end{tabular}

Abbreviations: sst $=$ sandstone

* Local values of thickness in excess of $1 \mathrm{~m}$ occur in the eastern part of Dionysus Hill (fig. 9, lower-left), but such thicknesses are not maintained over long distances laterally (only a few meters, or at most $10 \mathrm{~s}$ of $\mathrm{m}$ ). Rather, thicknesses $>1 \mathrm{~m}$ seem to indicate the sites of channels, as the level of the lower surface of AH-2 fluctuates more than its upper surface. These channels are probably oriented north-south $\pm 30^{\circ}$, as also suggested by the contour patterns on the isopleth map (fig. 9, lower-right). 
Table 3. Occurrences of Accretionary Lapilli at Southern Allan Hills

\begin{tabular}{|c|c|c|c|c|c|}
\hline \multirow{2}{*}{ Section } & \multirow{2}{*}{$\begin{array}{l}\text { Interval } \\
\quad(\mathrm{m})\end{array}$} & \multirow{2}{*}{$\begin{array}{c}\text { Bed } \\
\text { thickness } \\
\text { (m) }\end{array}$} & \multirow{2}{*}{ Lithology } & \multicolumn{2}{|c|}{ Accretionary lapilli (a.1.) } \\
\hline & & & & Proportion & $\begin{array}{l}\text { Size } \\
(\mathrm{cm})\end{array}$ \\
\hline $2 \mathrm{~A}$ & $17.3-19.3$ & 2.0 & Fine $\mathrm{LT}_{\mathrm{h}}$, just below block-rich layer $\mathrm{AH}-1$ & $1-3 \%$ & $\leq 1.0$ \\
\hline$"$ & $26.1-30.9$ & 4.8 & $\mathrm{LT}_{\mathrm{h}}, 0 \%$ blocks, $1 \%$ rags, $4.2 \mathrm{~m}$ below base of "gray layer" & $3 \%$ & $\leq 1.5$ \\
\hline $3 \mathrm{~A}$ & $117.8-117-9$ & 0.1 & $50 \%$ rim-type a.l. (fig. $12 \mathrm{~b}$ ); ash matrix & $50 \%$ & $\leq 4.5$ \\
\hline$"$ & $117.9-124$ & 6.1 & $\begin{array}{l}\text { Lapilli-tuff, } 40 \% \text { other lap (glassy basalt }>\text { rags, but rags locally } \\
\text { dominant and } \leq 15 \mathrm{~cm} \text {; fig. } 12 \mathrm{a} \text { ) }\end{array}$ & $2-15 \%$ & $\leq 2.5$ \\
\hline $3 \mathrm{~B}$ & $6.2-6.4$ & 0.2 & The lower $20 \mathrm{~cm}$ of block-rich layer AH-4 & a few & $\leq 2.5$ \\
\hline \multicolumn{2}{|c|}{$\begin{array}{l}\text { Southernmost Allan } \\
\text { Hills }\end{array}$} & 0.75 & $\begin{array}{l}\text { Coarse tuff just below a Beacon-rich layer (fig. 12c), } 1.4 \mathrm{~km} \mathrm{SW} \text { of } \\
\text { Ballance Peak }\end{array}$ & $\geq 20 \%$ & $\leq 1.0$ \\
\hline \multicolumn{2}{|c|}{$\begin{array}{l}\text { Southernmost Allan } \\
\text { Hills }\end{array}$} & $?$ & $\begin{array}{l}\text { Below a block-rich layer, in association with thin beds and bomb } \\
\text { sags, } 1.25 \mathrm{~km} \text { W-NW of Ballance Peak }\end{array}$ & $?$ & $\leq 1.0$ \\
\hline
\end{tabular}

Note. Other accretionary lapilli were noted in passing on NE side of Dionysus Hill.

Table 4. Characteristics of Non-Bedded, Basalt-Rich, Poorly Sorted Tuff-Breccia or Coarse Lapilli-Tuff ( TB $_{\mathrm{j}}$ ) Bodies

- Non-bedded $\mathrm{TB}_{\mathrm{j}}$ bodies invade and/or underlie both thick \& thin layers; large non-bedded $\mathrm{TB}_{\mathrm{j}}$ crops out only at the lowest topographic levels.

- Where both non-bedded $\mathrm{TB}_{\mathrm{j}} \&$ layered rocks are exposed (such as at base of stratigr. section $3 \mathrm{~A}$, in saddle area \& elsewhere), the former have steep to sub-vertical contacts $\mathrm{w} /$ the latter, thus demonstrating a crosscutting, 'invasive' origin.

- In term of grain size \& componentry, these $\mathrm{TB}_{\mathrm{j}}$ zones are entirely comparable w/ their Coombs Hills equivalents, including presence of unfragmented (coherent) glassy basalt pods \& in situ peperite domains + local abundance of composite clasts; equivalence of componentry was verified with field clast counts \& statistical tests (see Ross 2005 for details) 
Figures

a

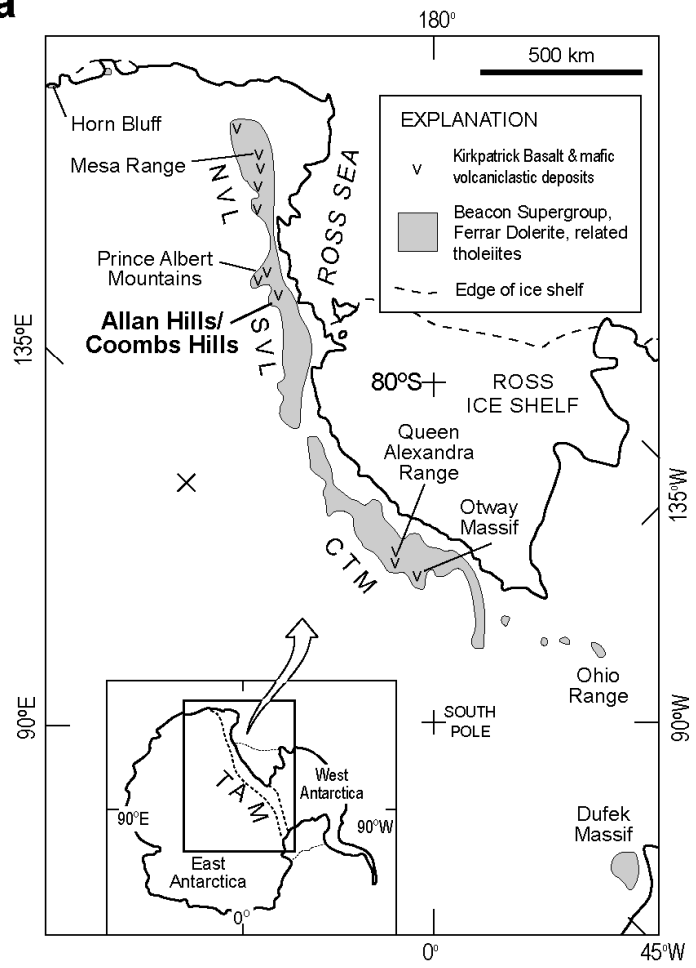

b

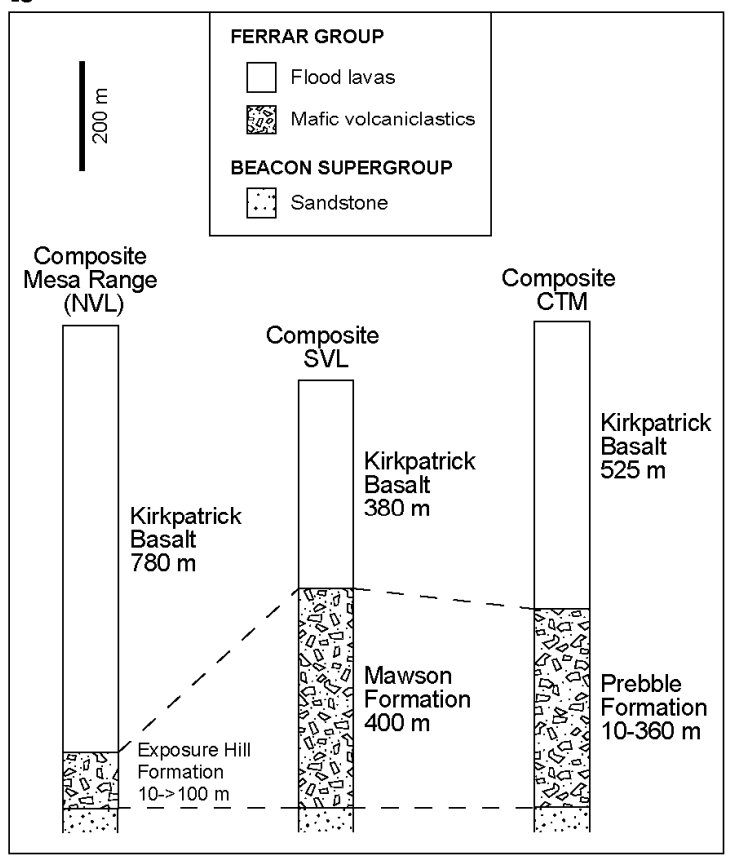

C

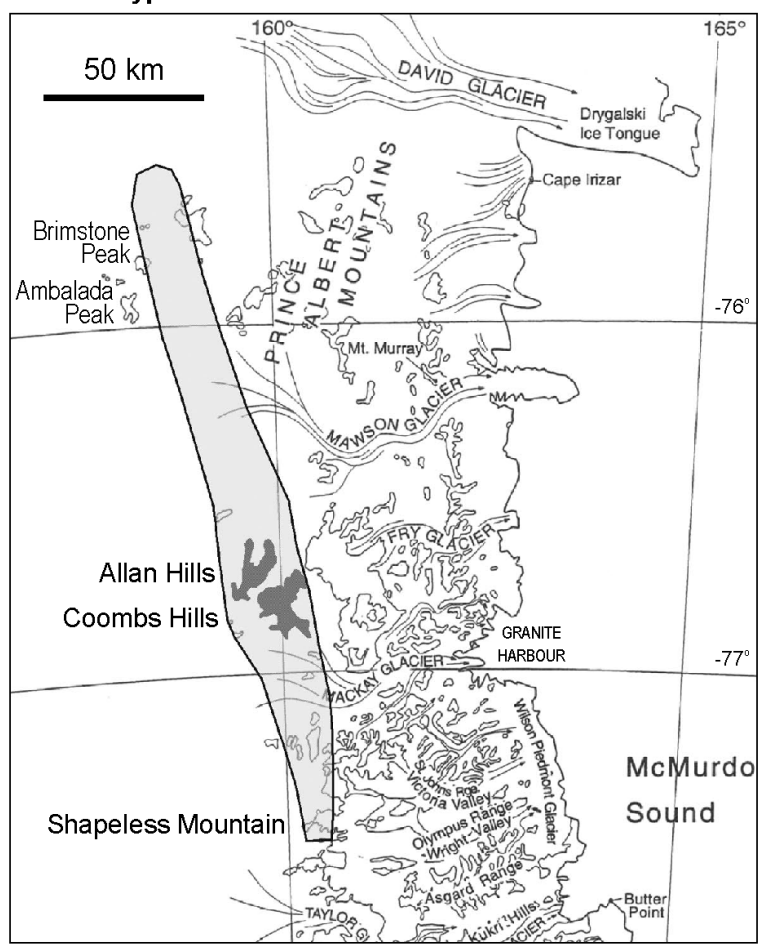

d

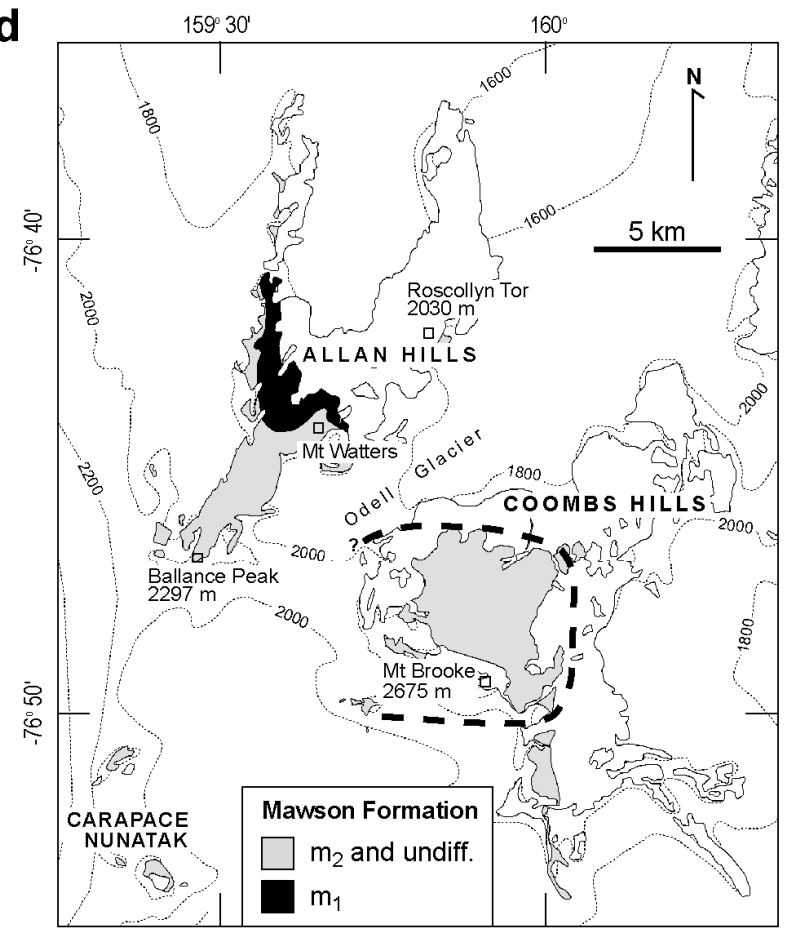

1. (a) Map showing the distribution of the Beacon Supergroup, Ferrar Dolerite, and Kirkpatrick Basalt in the Transantarctic Mountains (TAM). Mafic volcaniclastic deposits, including the Mawson Formation, are found underlying the Kirkpatrick Basalt in North Victoria Land (NVL), South Victoria Land (SVL) and the Central Transantarctic Mountains (CTM). Redrawn after Hanson and Elliot (1996). (b) Summary stratigraphic sections of the Ferrar Group showing flood lavas and mafic volcaniclastics (thicknesses after Elliot 2000). (c) Hypothetical former distribution of the Mawson Formation, interpolating between known occurrences. The illustrated belt is $\sim 195 \mathrm{~km}$ long, with a mean width of $\sim 21 \mathrm{~km}$. Exposed thicknesses are generally over $60 \mathrm{~m}$. Base map modified from Stump (1995). (d) Present-day distribution of the Mawson Formation in the Coombs-Allan Hills area of SVL, based on Grapes et al. (1974), McClintock (2001), and new mapping. The inferred limit of the vent complex at Coombs Hills is shown by the bold dashed line. Elevations contours (ice-covered areas only) are in meters above sea level. 


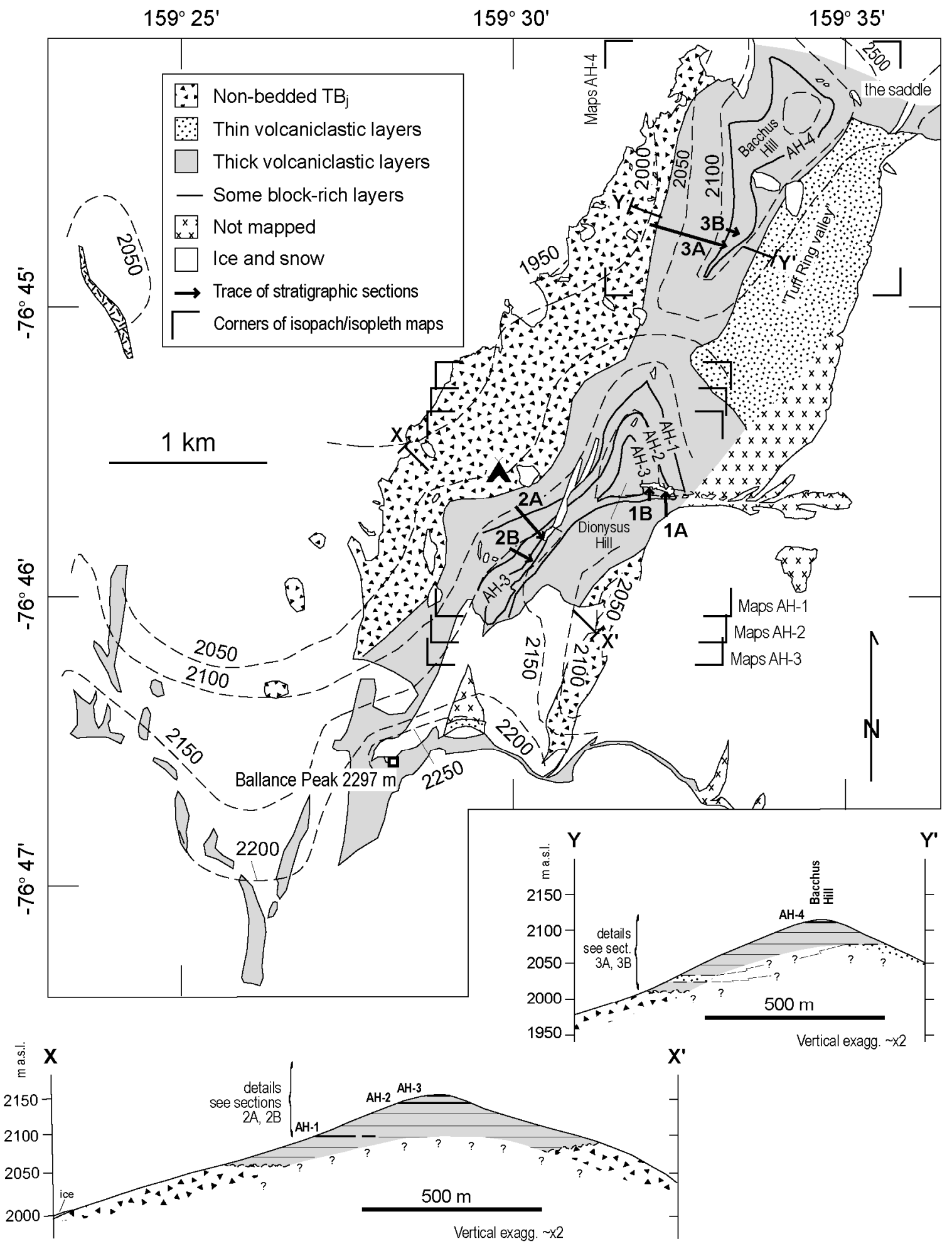

2. Geological map and cross-sections of southern Allan Hills, based entirely on new mapping (Ross 2005). The total surface area occupied by the Mawson Formation there is about $8.5 \mathrm{~km}^{2}$ (including snow patches and localized screecovered zones), of which $7.8 \mathrm{~km}^{2}$ was mapped in late 2003. The location of stratigraphic sections is shown by bold arrows. Bold lines marked $\mathrm{AH}-1$ to $\mathrm{AH}-4$ indicate block-rich layers discussed in the text, and corner signs show the limits of the isopach and isopleth maps for these layers (figs. 9-10). Thin horizontal lines in cross-sections X-X' and Y$Y^{\prime}$ schematically represent the attitude of the thick volcaniclastic layers. Snow patches and outcrop outlines from aerial photograph TMA-2494-066 (registered using GPS data), except western third of the map from a Landsat image. New $50 \mathrm{~m}$ topographic contours in meters above sea level (calculated as WGS84 elevation $+53 \mathrm{~m}$ ) were drawn from over 300 GPS spot heights. Ballance Peak is an official name; Dionysus Hill, Bacchus Hill, "Tuff Ring valley" and "the saddle" are informal names. 


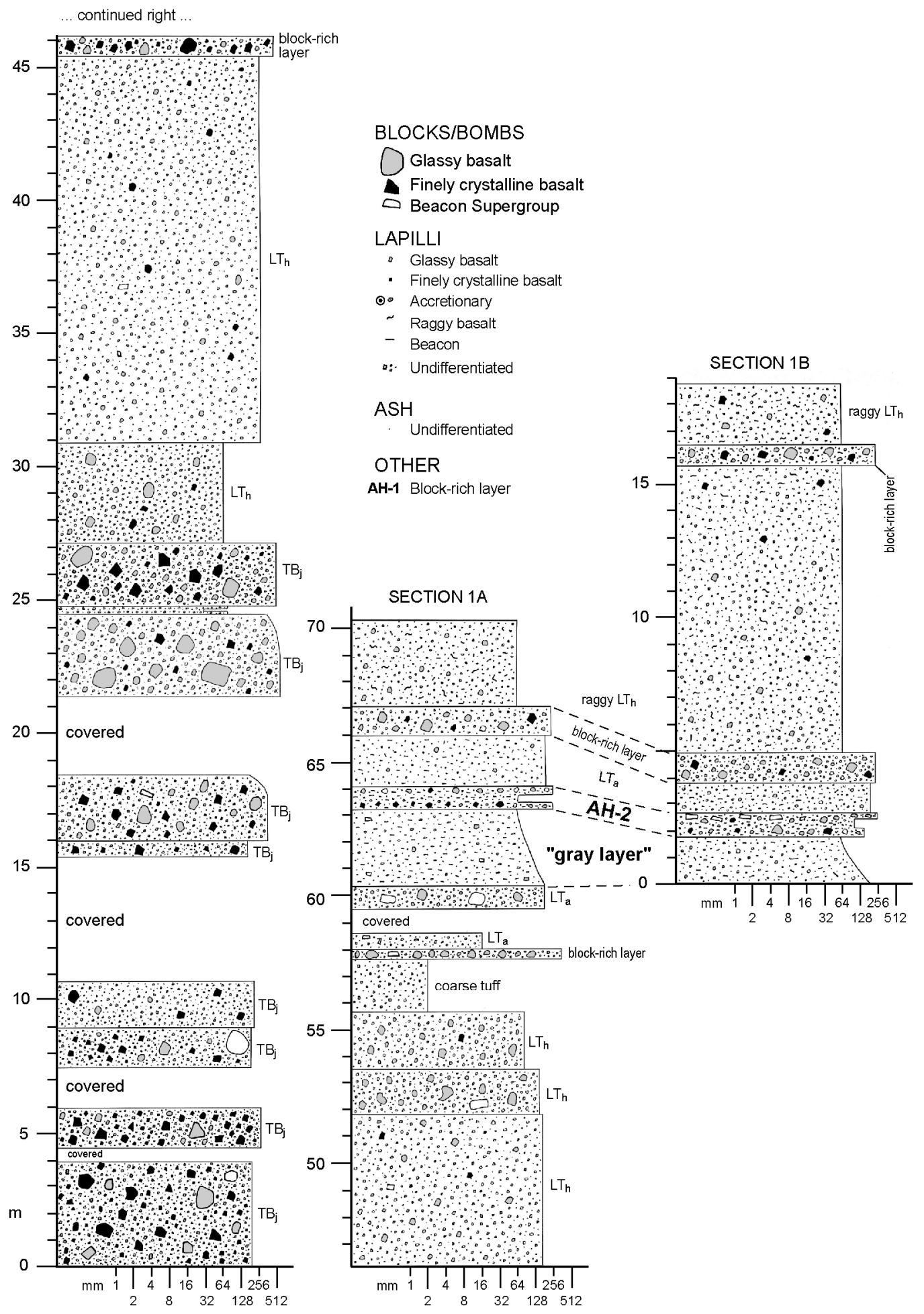

3. Stratigraphic sections 1A and 1B in the thick volcaniclastic layers, on the south side of Dionysus Hill (fig. 2) at southern Allan Hills. The columns show a succession of at least eight basalt-rich tuff-breccia $\left(\mathrm{TB}_{\mathrm{j}}\right)$ beds overlain by a number of heterolithological lapilli-tuff $\left(\mathrm{LT}_{\mathrm{h}}\right)$ layers interbedded with coarse tuff beds, block-rich layers (including $\mathrm{AH}$ 2) and Beacon-rich lapilli-tuff $\left(\mathrm{LT}_{\mathrm{a}}\right)$ beds including the "gray layer". $\mathrm{LT}_{\mathrm{h}}$ beds include raggy glassy basalt clasts near the top of the sections. No accretionary lapilli are found here. For figures 3 to 5, the width of the stratigraphic units on the columns represents the average size (in $\mathrm{mm}$ ) of the five largest clasts in each unit, or the 'typical' grainsize for units lacking coarse fragments. Symbolic blocks and lapilli in the columns are approximately scaled relative to each other, but not necessarily relative to the vertical scale of sections. Some contacts between units are more gradational than they appear on the sections. 


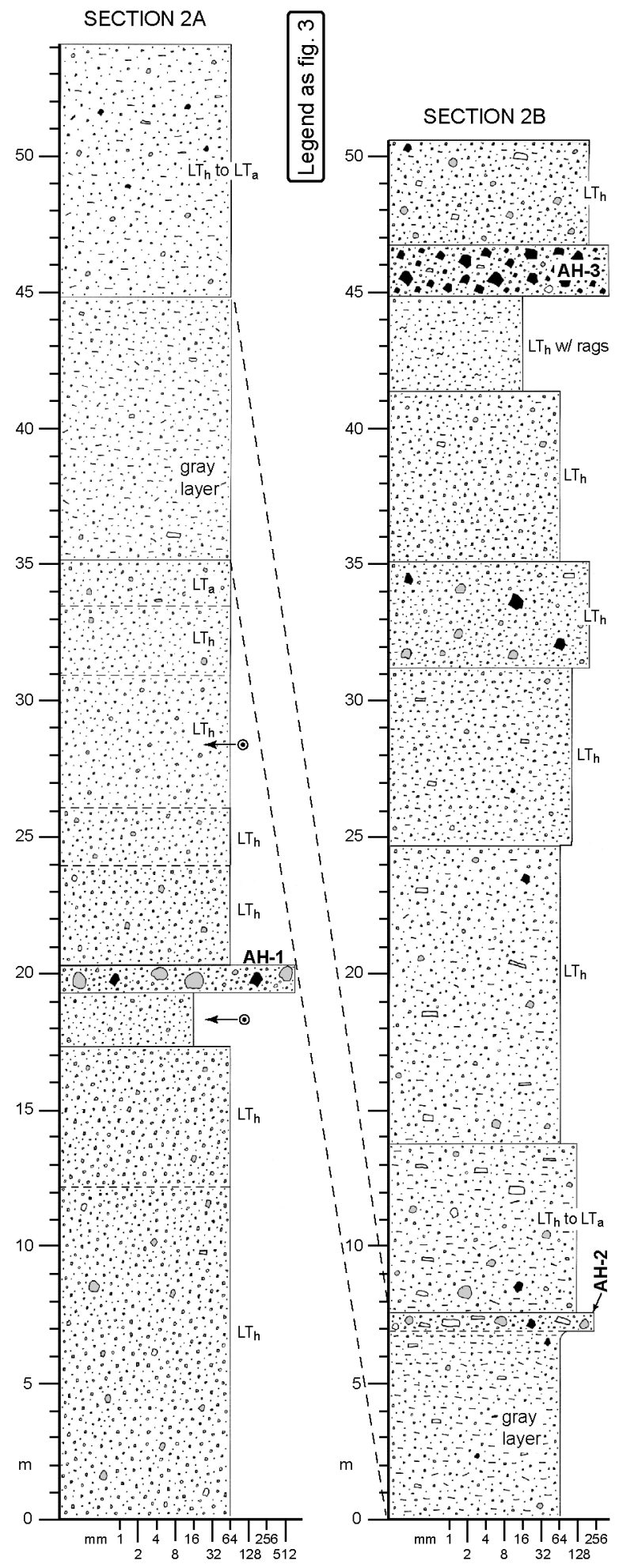

4. Stratigraphic sections $2 \mathrm{~A}$ and $2 \mathrm{~B}$ in the thick volcaniclastic layers on an unnamed hill (fig. 2) at southern Allan Hills. The columns show a succession of heterolithological lapilli-tuff $\left(\mathrm{LT}_{\mathrm{h}}\right)$ layers interbedded with a fine lapilli-tuff bed, block-rich layers (including AH-1, AH-2 and AH-3) and Beacon-rich lapilli-tuff (LT ${ }_{\mathrm{a}}$ ) beds including the "gray layer". Accretionary lapilli are present in the fine lapilli-tuff bed just under AH-1 and in a coarse $\mathrm{LT}_{\mathrm{h}}$ bed several meters above AH-1 (see table 3 for details). See the caption of figure 3 for comments on how the sections were drawn. 

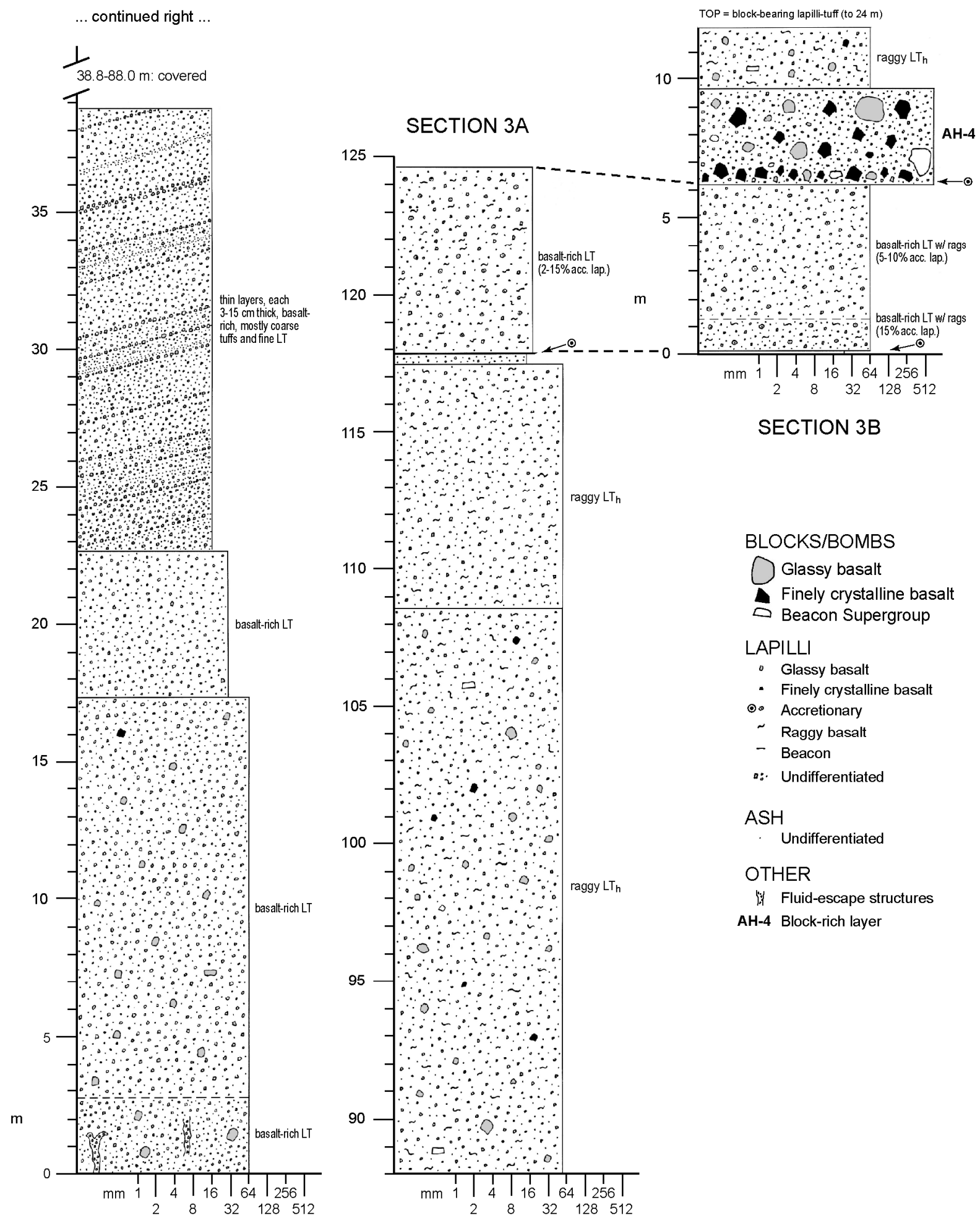

5. Stratigraphic sections $3 \mathrm{~A}$ and $3 \mathrm{~B}$ in the thick volcaniclastic layers on the west side of Bacchus Hill (fig. 2) at southern Allan Hills. This section actually includes a sequence of thin inclined layers between 22.7 and $38.8 \mathrm{~m}$. The thick layers consist of basalt-rich lapilli-tuff (LT; not clearly assignable to the regular facies cited in table 1) under the thin layers, and then mostly heterolithological lapilli-tuff $\left(\mathrm{LT}_{h}\right)$ beds containing raggy basalt clasts above the thin layers. Block-rich layer AH-4 is present near the top of section 3b; accretionary lapilli are present in three different beds (see table 3 for details). See the caption of figure 3 for comments on how the sections were drawn. 

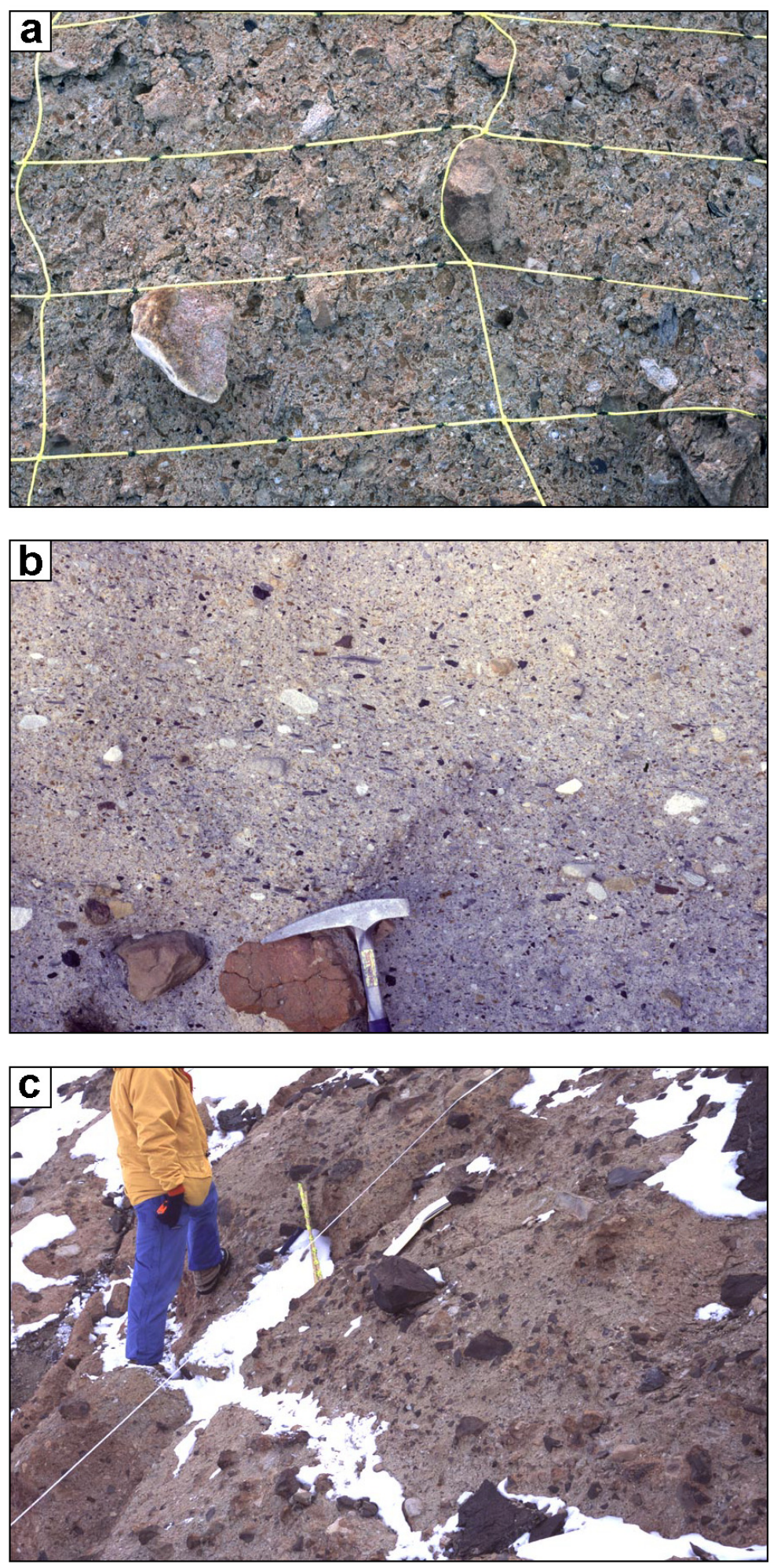

6. Photographs of poorly sorted lapilli-tuffs and tuff-breccias (thick layers). (a) Heterolithologic lapilli-tuff (LT $\mathrm{LT}_{\mathrm{h}}$ from section 1A, 31-55 m; the closed-spaced strings on the clast-counting net a spaced by $10 \mathrm{~cm}$. (b) The "gray layer", a Beacon-rich lapilli-tuff, section 2A, 35-45 m; note the sub-horizontal alignment of elongate clasts. (c) Basalt-rich tuffbreccia $\left(\mathrm{TB}_{\mathrm{j}}\right)$, section $1 \mathrm{~A}, 0-9 \mathrm{~m}$; note the sub-horizontal layering plane shown by variations in the size of basaltic blocks; white color is overexposed snow. 


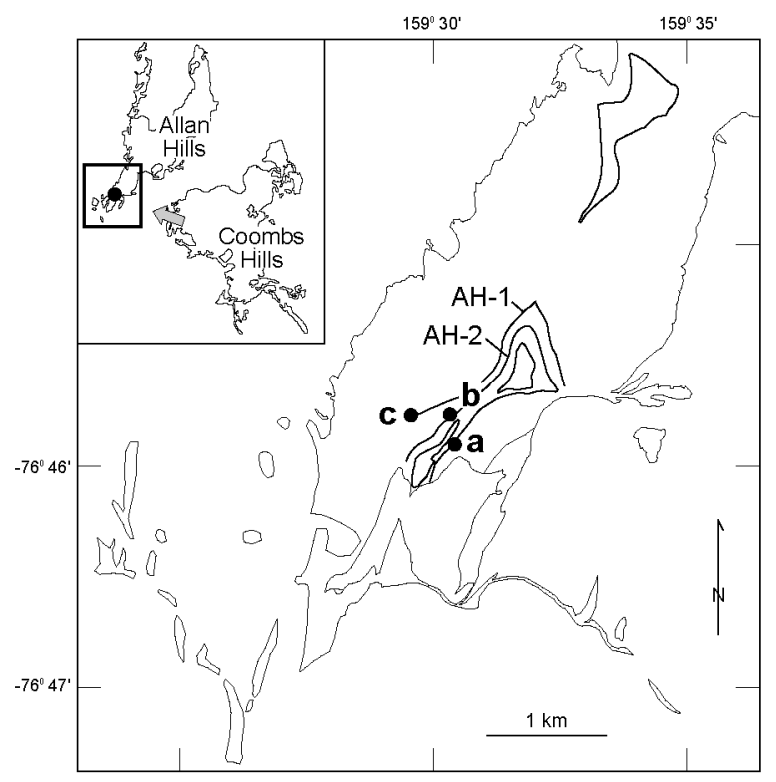

b

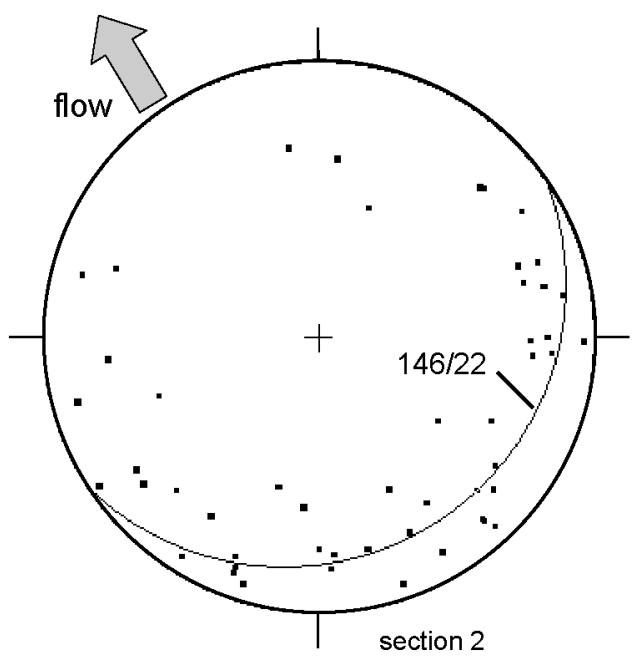

a

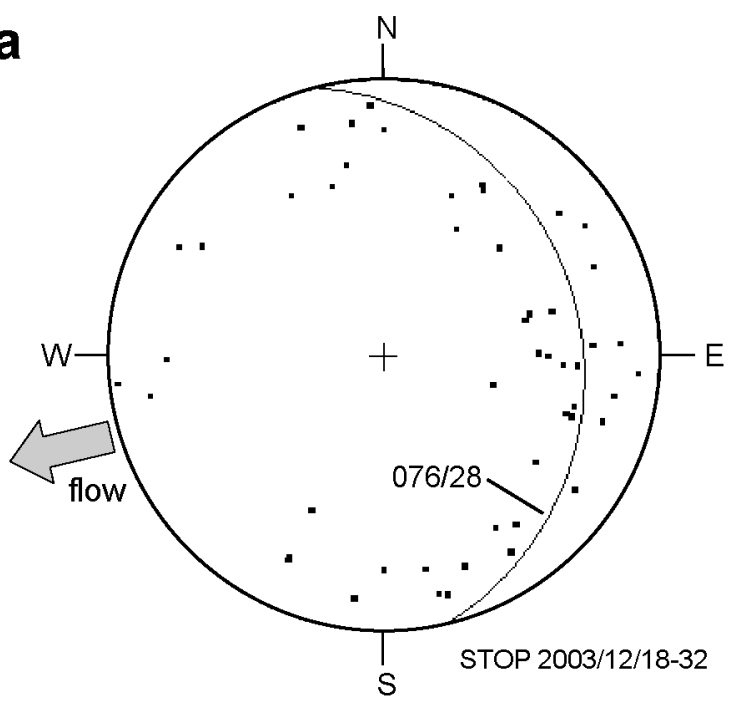

C

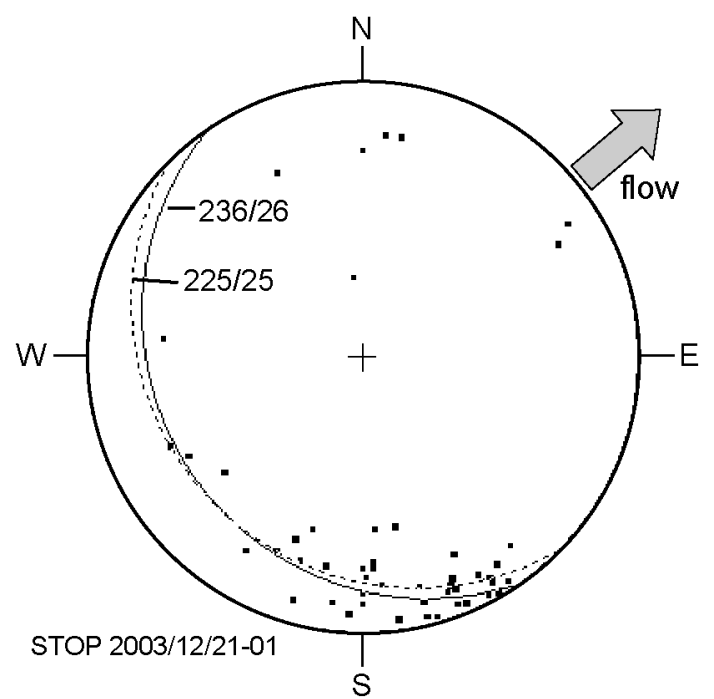

7. Paleocurrent directions (arrows) for volcaniclastic layers determined from the imbrication of clasts. Lower hemisphere stereoplots show the dip and dip direction of the plane of 50 tabular clasts per site, and a computer-selected girdle [dashed line in (c) is hand-picked]. It is inferred that the clasts dip toward their source. Sites (a) \& (b) are from a Beacon-rich lapilli-tuff ("gray layer") just under block-rich layer AH-2, and (c) is from a lapilli-tuff just under blockrich layer AH-1 (see sketch map for locations). The average of the inferred directions for the gray layer indicates Coombs Hills as a possible source (see inset map); for plot (c) the indicated source is to the southwest or south, an area now covered by ice. 


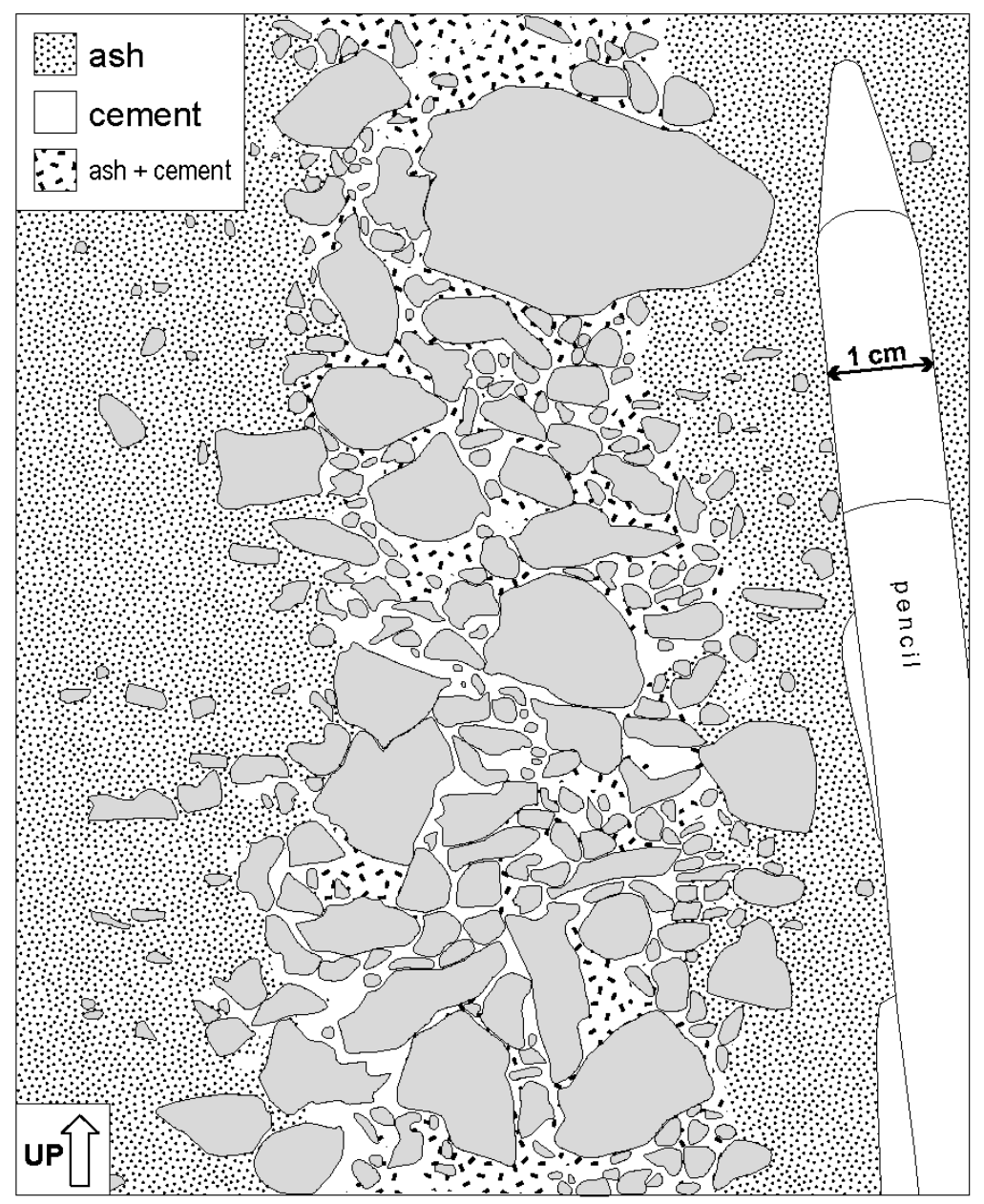

8. Line drawing from a photograph of a sub-vertical fines-depleted pipe in a coarse tuff layer. The "pipe" contains more cement, more lapilli, and less ash than its host, and could have been formed by (i) gas fluidization during or soon after deposition from a pyroclastic density current; (ii) elutriation by water in a debris flow deposit; or (iii) aggregative fluidization of the deposit during post-emplacement hydrothermal circulation above shallow basaltic intrusions (see Ross 2005 and Ross and White 2005 for further discussion of lapilli pipes). 

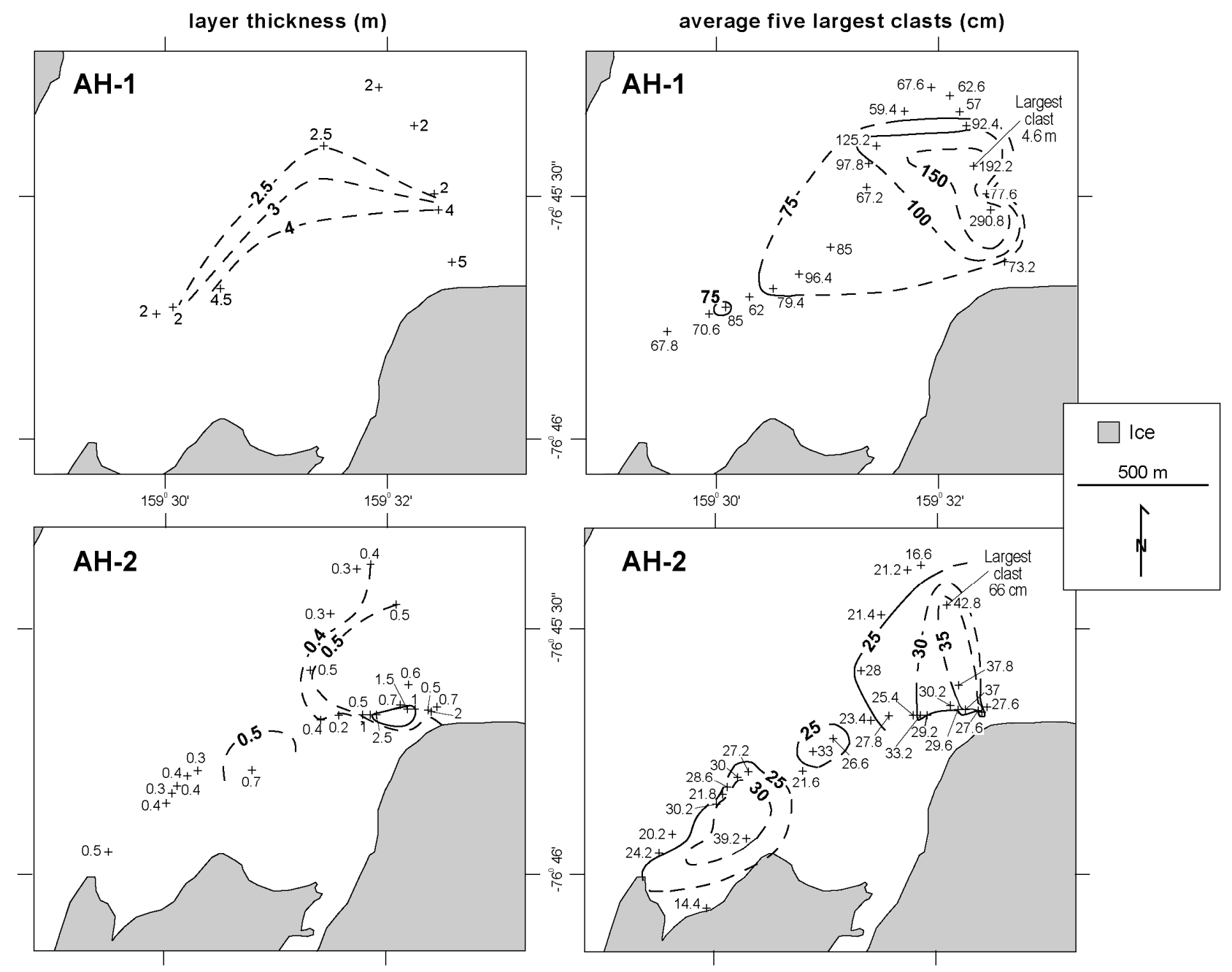

9. Isopachs (left, in meters) and isopleths (right, in $\mathrm{cm}$ ) for block-rich layers AH-1 and AH-2, southern Allan Hills. Thickness and clast size information was gathered approximately every $50 \mathrm{~m}$ laterally; the five largest clasts were measured within $3 \mathrm{~m}$ laterally at each station. Thickness values on individual isopach maps are only displayed where the layer is fully exposed. See figure 2 for map locations and table 2 for a discussion of trends in isopachs and isopleths. 

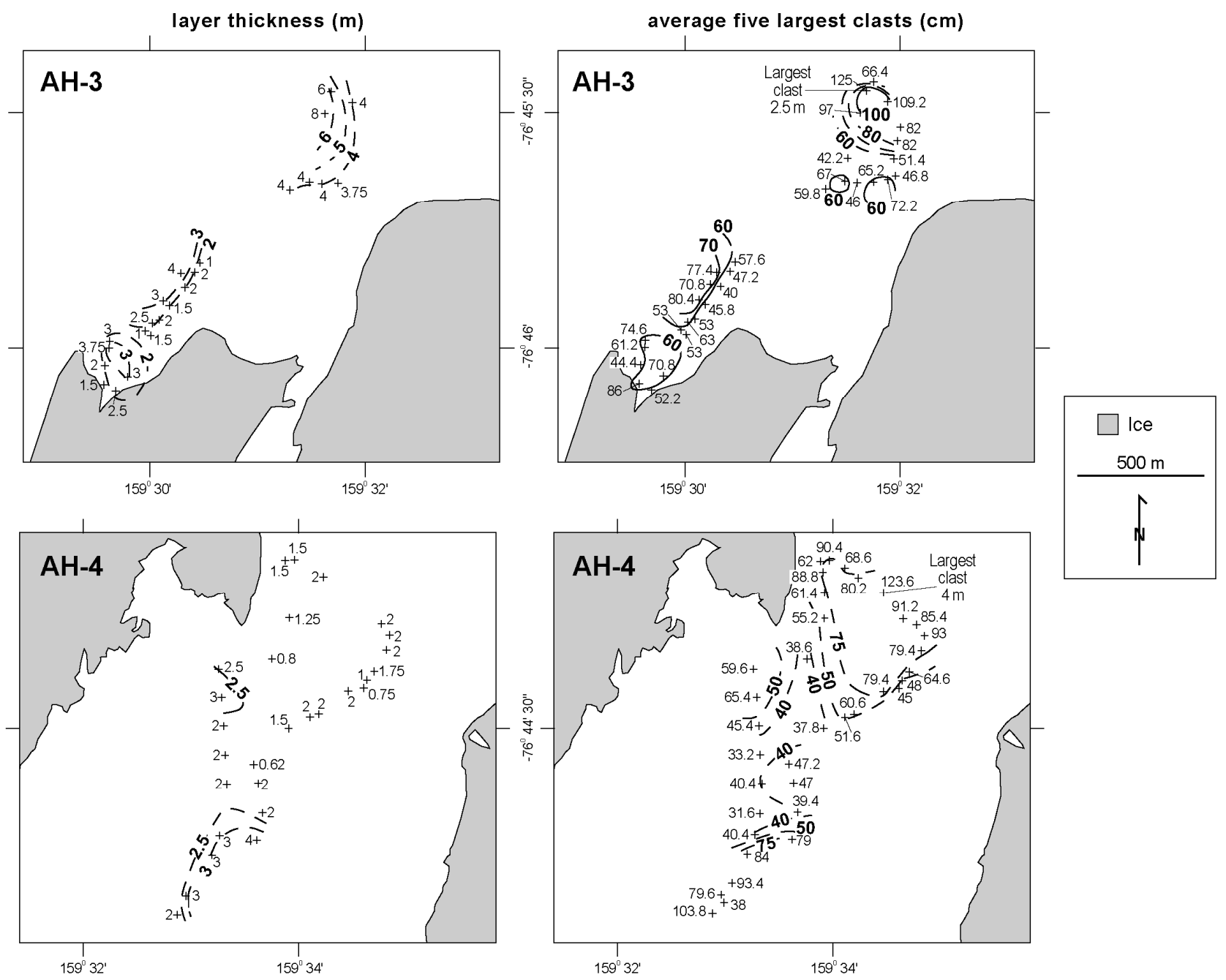

10. Isopachs (left, in meters) and isopleths (right, in cm) for block-rich layers AH-3 and AH-4, southern Allan Hills. Methods as for figure 9. See figure 2 for map locations and table 2 for a discussion of trends in isopachs and isopleths. 

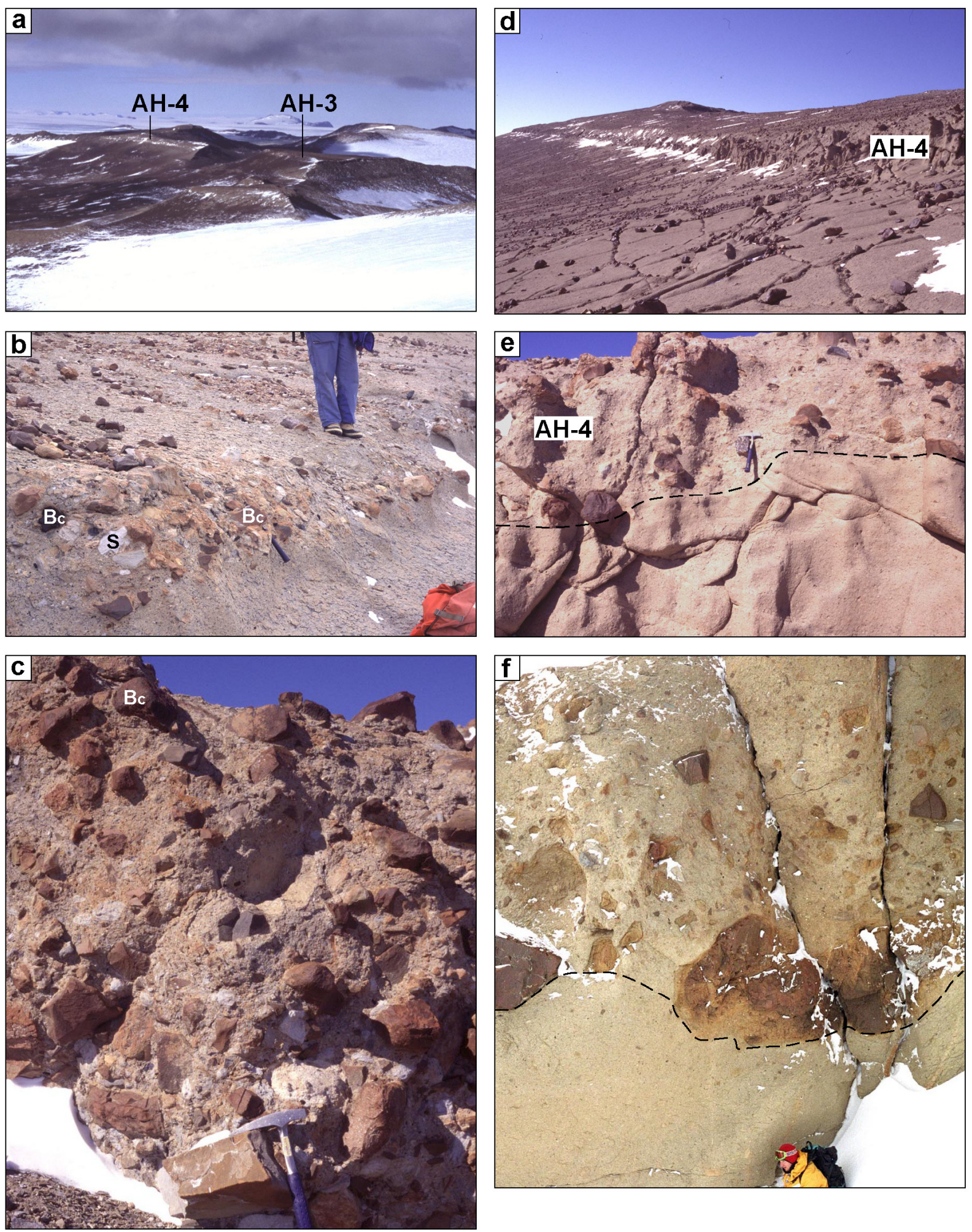

11. Photographs of block-rich layers. (a) View looking north-northeast from Ballance Peak (see fig. 2), showing AH-3 forming the flat top of Dionysus Hill, and AH-4 forming a prominent slope break, marked by a snow accumulation, near the summit of Bacchus Hill. (b) Detail of AH-2, showing the abundance of sandstone blocks (S) and clasts of finely crystalline basalt $\left(\mathbf{B}_{\mathbf{c}}\right)$ (stratigr. section 1A). (c) Detail of AH-3, showing the dominance of finely crystalline basalt in the block fraction (stratigr. section 2B). (d) General view, looking north-eastwards, of AH-4 on Bacchus Hill; the block-rich layer is 2 to 3 m-thick there. (e) Detail of AH-4 (top eroded off) showing a slightly undulating base, and a tuff or fine lapilli-tuff layer underneath. (e) Unnamed, laterally discontinuous block-rich layer in the saddle area, showing coarse-tail normal grading, and an undulating base due to penetration of large basaltic bombs in the underlying tuff layer. 

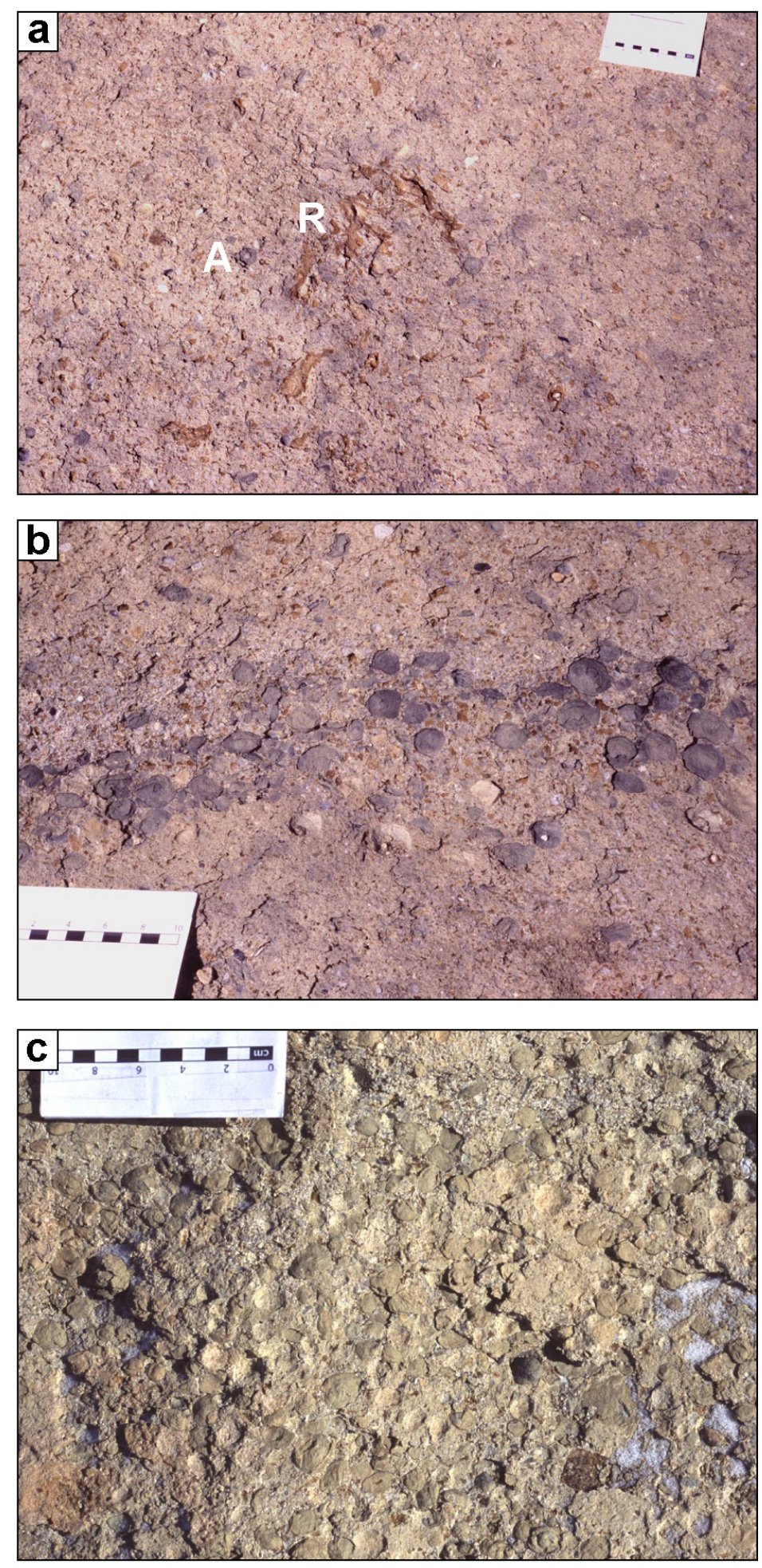

12. Photographs of accretionary lapilli-bearing layers. (a) A peculiar mix of raggy basaltic clasts (R) and accretionary lapilli (A) on Bacchus Hill. The accretionary lapilli indicate a cool, moist eruption plume or current whereas the 'rags' need to stay hot until deposition to be able deform plastically and accommodate surrounding clasts before solidifying. (b) A $10 \mathrm{~cm}$-thick layer with up to 50\% rim-type a.l., also on Bacchus Hill; note the exceptionally large size of the a.l. (c) Layer in southernmost Allan Hills. Scale bar on notebook is in centimeters. 


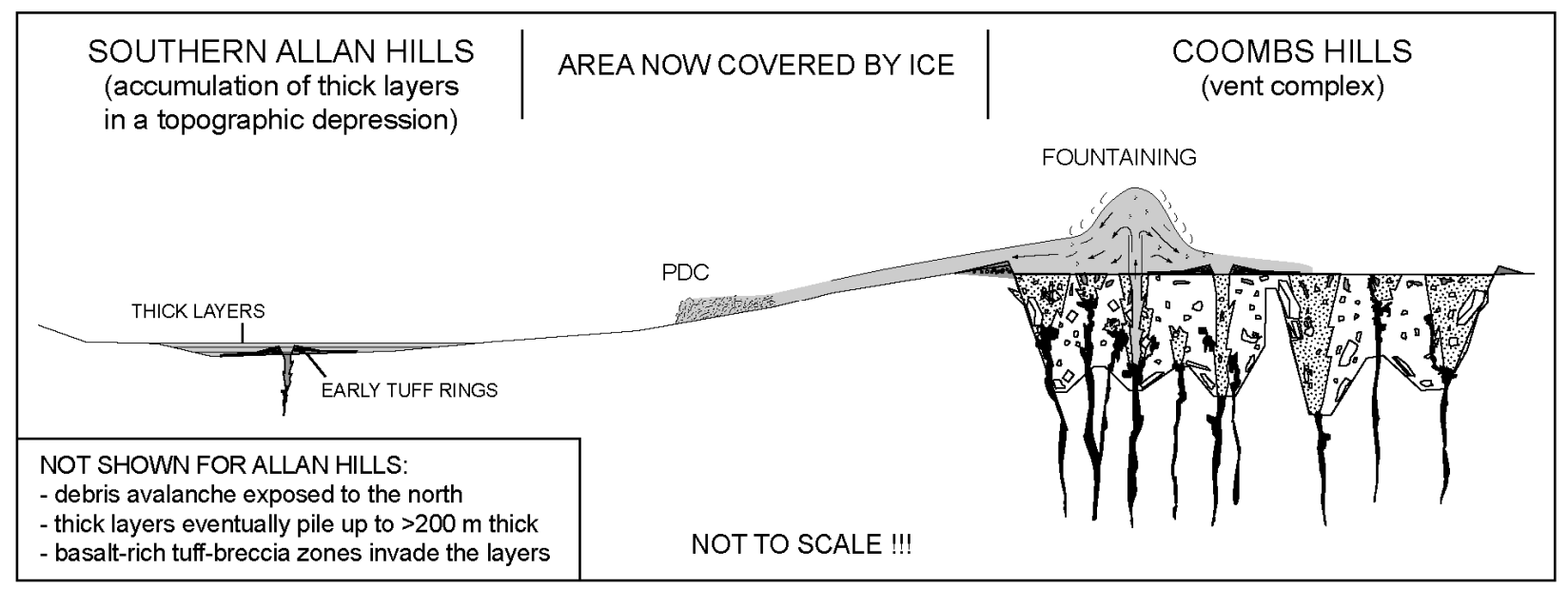

13. Hypothetical cartoon (cross-section) showing a moderate-sized, collapsing eruption plume (regime 2 of Houghton et al. 2004) above the Coombs Hills vent complex. The cartoon shows a fully developed vent complex (modified from White and McClintock 2001) but this is not necessary, as similar eruption plumes could have developed earlier. The fountain feeds high-concentration pyroclastic density currents, which under the influence of gravity follow the downward slope towards southern Allan Hills. The latter location is inferred to have been a topographic depression before the start of explosive eruptions in the Jurassic, because of erosion of the Beacon sequence (several 100s $\mathrm{m}$ of erosion). Before the thick layers started to accumulate there, tuff rings had already started to grow from local vents. Not shown on the diagram are $\mathrm{TB}_{\mathrm{j}}$ zones that eventually invaded both the thin and the thick volcaniclastic layers at southern Allan Hills, and the Kirkpatrick flood basalts that flooded the entire landscape after the end of explosive eruptions. 